\title{
Insecurity of Property Rights and Social Matching in the Tenancy Market
}

October 2009

\author{
Karen MACOURS ${ }^{1}$, Alain de JANVRY ${ }^{2}$, and Elisabeth SADOULET ${ }^{2}$ \\ ${ }^{1}$ Johns Hopkins University and ${ }^{2}$ University of California at Berkeley
}

\begin{abstract}
This paper shows that insecurity of property rights over agricultural land can have large efficiency and equity costs because of the way it affects matching in the tenancy market. A principal-agent framework is used to model the landlord's decision to rent when he takes into account the risk of losing the land to the tenant and when contract enforcement is decreasing in social distance with the tenant. These effects are quantified for the case of local land rental markets in the Dominican Republic. Results show that insecure property rights lead to matching in the tenancy market along socio-economic lines, severely limiting the size of the rental market and the choice of tenants for landlords, both with efficiency costs. Social segmentation reduces access to land for the rural poor, with high equity costs. Simulations suggest that improving tenure security would increase rental transactions by $21 \%$ and the area rented to the poor by $63 \%$. Increased property rights security is hence beneficial not only to asset owners, but also to those with whom they might interact in the market.
\end{abstract}




\section{Introduction}

Much attention has recently been given to the fact that property rights are frequently highly insecure in developing countries, and that this insecurity can have high efficiency and equity costs. Efficiency costs of property rights insecurity have been analyzed through its effects on investment, access to credit, and labor supply; equity costs through differential security between rich and poor leading to cumulative divergences in investment and income. This paper provides evidence on an additional mechanism through which insecurity of property rights bears on development. It shows how insecurity of property rights over agricultural land induces the land rental market to be segmented along socio-economic lines. It further shows that this results in high efficiency and equity costs, and contributes to the reproduction of deep-rooted local inequalities.

We quantify this effect for local land rental markets in two regions of the Dominican Republic. For each local market, exhaustive records were collected on all land transactions with information on households on the two sides of the market, a large sample of non-participating households, and identification of potential tenants that were constrained out of the market. By simulating the effect of strengthening property rights on land rental market decisions, we show that large efficiency and equity gains can be achieved when formal titles are granted, land conflicts are reduced, and property rights are more effectively enforced. The simulations are based on an empirical estimation of the assortative matching between landlords and tenants in these markets. The underlying theoretical model uses a principal-agent framework, in which the landlord chooses his tenant taking into account the incentive that the tenant has to squat and the risk that this would result in loss of the plot. With the capacity to enforce contracts decreasing in social distance with the tenant, rental transactions are confined within the same social class. Estimation results support the hypothesis that property rights insecurity reduces the level of activity on the land rental market and confines the choice of tenant to socially proximate individuals, creating inefficiencies. Insecurity of property rights then also limits access to land for the poor, both in numbers and in share of the market. This paper thus brings to light a powerful mechanism through which inequality can be reproduced at the local level over potentially long periods of time. With growing evidence on the efficiency and social costs of inequality (Ravallion, 2001), our results uncover an important mechanism through which this phenomenon occurs. This question is particularly relevant for Latin America where income inequality is among the highest in the world (Bourguignon and Morrison, 2002), where it has been stubbornly persistent over the centuries (De Ferranti et al., 2004), and where access to land plays a key role for these phenomena in rural areas. 


\section{Security of property rights and social segmentation}

While recognizing the fundamental role of property rights for development is not recent (see for example the seminal contributions of the Property Rights School with Demsetz, 1967, and Davis and North, 1971), important progress has been made in recent years in rigorously quantifying this role and the channels through which it happens. A growing body of evidence has thus shown the role of security of property rights on investment incentives and access to credit for owners (Feder and Feeny, 1991; Besley, 1995; Jacoby, Li, and Rozelle, 2002; Johnson, McMillan, and Woodruff, 2002). The relation can sometimes be negative: Braselle, Gaspart, and Platteau (2002) observe that land tenure insecurity in Burkina Faso induces investment in tree planting as a way of establishing rights. But Deininger and Jin (2006) find for Ethiopia that while insecure tenure encourages planting of trees it discourages productivity enhancing investments such as terracing. In other cases, the relation is weak or socially confined: Do and Iyer (2008) find positive but small investment effects of a property rights reform in Vietnam, and Carter and Olinto (2003) show that greater property rights security only leads to positive investment effects among wealthier producers. But there is also evidence that the relation can be positive and large: Field (2005, 2007) and Galiani and Schargrodsky (2005) find positive effects of stronger property rights on labor supply and housing investments in urban squatting settings in Peru and Argentina. Di Tella et al. (2007) uncover a potentially important mechanism whereby this happens when property rights security enhances people's beliefs in the market economy.

The literature on security of property rights and inequality has also evidenced existence of a difference in insecurity between rich and poor, with the rich and powerful better able to protect their assets than the poor (de Soto, 2000; Lanjouw and Levy, 2002; Goldstein and Udry, 2008). This difference can lead to the perpetuation of weak property rights institutions in unequal societies as rich elites are not necessarily interested in using the state to increase the security of property rights (Glaeser et al., 2003; Gradstein, 2007). A vicious circle of rising inequality can then emerge as it induces (via incentives to invest, access to credit, and beliefs in markets) a growing divergence in investment and efficiency across these social groups.

This paper uncovers a different channel through which property rights insecurity can lead to the perpetuation of inequality. It shows that property rights insecurity over productive assets can have an impact not only on the direct use of assets by owners, but also on how they select households with whom they decide to interact in markets for these assets. As such it relates to papers that analyze the effects of property rights insecurity on land market activity (Gine, 2005; Conning and Robinson, 2007) and the

efficiency and equity gains to be achieved through land rental markets (Deininger and Jin, 2005; Deininger et al., 2008). In our case, the risk of losing the land to the tenant induces landlords to select households from the same social class, reproducing social inequalities. We recognize that insecurity can be caused not 
only by lack of formal titles but also by lack of informal enforcement of property rights and by the recent history of land conflicts. ${ }^{1}$ The paper measures the extent to which land rental market activity can be socially biased as a consequence of the lack of formal or informal property rights, and the magnitude of the resultant efficiency and equity costs.

\section{The land rental market and property rights insecurity in the Dominican Republic}

The highly unequal distribution of land ownership in most Latin American countries suggests that there is room for redistribution of land under cultivation through the land rental market. Yet, only $12 \%$ of agricultural land is rented in Latin America and 14\% in the Dominican Republic, compared to $41 \%$ in the United States and 67\% in Belgium (FAO, 1981). Field observations provide plenty of evidence that land markets do not function well in the Dominican Republic. In our survey, $64 \%$ of all households that do not rent to others said that they would like to rent more land from others. In spite of this, field visits in these communities reveal that there are extensive tracts of underused land, mainly in the hands of large landowners who use it at most for extensive grazing when it could be rented out more profitably.

Furthermore, Latin American land rental markets tend to be segmented, with the land being transacted mainly among people of the same socio-economic class (Carter and Chamorro (2001) for Nicaragua). We hypothesize that this segmentation deepens with insecurity of property rights. Table 1 shows the correspondence in living standards of landlords and their tenants in our survey, distinguishing between communities with and without recent land invasions. ${ }^{2}$ The first panel shows that in communities with recent land invasions, there is a very strong positive assortative matching along living standards. More than half of the transactions are between members of the same class. Less than $7 \%$ of the land transacted by the rich is rented out to the poor (low living standard), and vice versa. By contrast, transactions are more equally distributed across classes in communities without land invasions (second panel), with $41 \%$ of the plots rented out by the rich going to the poor. A Kolmogorov-Smirnov test confirms that the proportion of observations along the diagonal is larger in communities with recent land conflicts at the $1 \%$ significance level.

The rental market in the Dominican Republic works through short-term sharecropping contracts, fixed rent contracts, or contracts with payments in labor services. Many plots are rented on a seasonal basis, year after year, with the same tenant cultivating it for one season and the landlord for the rest of the year. In

\footnotetext{
${ }^{1}$ Most papers in the literature focus either on the impact of formal titles or look at informal property rights. With the exception of Lanjouw and Levy (2002), the different dimensions of property rights security are often not considered together.

${ }^{2}$ Section 5.1 explains how living standard classes are defined.
} 
our survey, $89 \%$ of the contracts with a defined length of time are for one year or less. The prevalence of short-term contracts is not surprising given laws granting possession rights to long-term occupants.

The insecurity of property rights that induces fear among landlords to lose their land is not unique to the Dominican Republic. It characterizes many Latin American countries with agrarian laws put into place during the period of state-led expropriative land reforms and institutional weaknesses in the land administration and judicial systems. These agrarian laws cause property rights insecurity because of regulations on land ownership (in many countries, laws grant ownership rights to occupants after a minimum number of years), or because of inconsistencies between constitutional constraints on land use to merit ownership and the Civil Code (e.g., Brazil and Venezuela). Lack of titles, outdated or overlapping titles, and slow, costly, and inaccessible legal systems further impede property rights security (Macours et al., 2002). In the Dominican Republic, land ownership and distribution have been affected by the different property rights regimes of successive foreign powers (Spanish, French, and United States) that were introduced without abolishing the previous system, and by the redistributive land reform initiated in the 1960s that remains inconclusive. Within a few years of the reform, redistribution of expropriated land, although now officially owned by the Dominican state, was stalled and the former - often absentee - owners maintained possession of most of the property. This invited land invasions by the rural population who claims that this land is property of the Dominican people and hence theirs. Legislation remains in place that allows for expropriation of under-used land, creating further incentives for land invasions (Gill, 2000). The resulting climate of property rights insecurity also induces squatting on other lands.

In the regions studied, invasions have had mixed results. In some cases, invaded land has been vacated by military force, but more often, invasions have led to some type of negotiated settlement, or long-term possession with continued uncertainty on property rights. In cases of squatting by tenants, property rights enforcement is also often weak, even when landlords have verifiable property rights. When a tenant seeks to squat, attempts to resolve the conflict can pass through different stages. First landlords might try to evict the tenant personally, possibly with the help of his family. In case this is unsuccessful, they might resort to community organizations to mediate the conflict. And in a next step, cases can be taken to court. The outcome of each of these processes is typically far from certain. Even in cases when landlords have verifiable property rights, enforcement can be weak, in part because the law often leaves room for competing claims. E.g., in a number of squatting cases that went through litigation, court decisions have favored poor squatters over rich landlords, based on land reform legislation that provides strong rights to occupants. On the other hand, among the poor there is also a perception that the justice system has generally favored the rich.

There is a relatively strong correlation between the recent occurrence of land invasions and squatting. Of the 18 communities in the survey, 8 had a land invasion in the last 5 years, and in 7 of these 8 there were cases of land squatting. Of the remaining 10 communities, 3 had a case of squatting in the last 5 
years. Extensive field interviews revealed that in communities with land invasions, local conflict resolution would often favor squatters, further increasing the incentives to squat, and therefore augmenting the general perception of property rights insecurity. It is important to note, however, that there is only a handful of plots on which tenants attempted to squat in any of these communities. This is not surprising given that landlords attempt to avoid such cases by carefully choosing their tenants. ${ }^{3}$

The impediments to land rental compound with the fact that land rental markets, by the very nature of the traded good, are local and small. Options are limited for landlords, and that is why they may end-up choosing not to rent-out. Conversely, potential tenants' opportunities to have access to a plot of land are limited by the relationships they have with landlords in the community. Hence, access to land for a particular tenant will not only depend on his own characteristics, but also on the characteristics of all available landlords and all other potential tenants in the community, and on the institutional context that might influence the landlords' preferences.

\section{Modeling the land rental market in the context of insecurity of property rights and the empirical specification}

To guide the empirical specification, we develop a model that focuses on enforcement of contracts through social ties as an explanation for the observed market segmentation. In deciding whom to rent out to, landlords take into account the probability of losing their land. They can pay a premium to reduce the incentive to squat. ${ }^{4}$ We assume that enforcement against squatting is easier for members of the same socioeconomic class, and that this holds for landlords from all classes. ${ }^{5}$ This is because people from the same class depend on each other for various other interactions, such as loans, referrals on labor markets, and mutual insurance.

As markets are local, landlords in any village only face a limited number of potential tenants, and may have to compete for the best tenants. In equilibrium, each landlord's strategy must be optimal given the strategies of the other landlords. Because of the localized nature of land rental transactions, we assume that landlords and tenants have full information on asset ownership and on the productive capacity of all potential partners. The assumption of perfect information about these characteristics is warranted for

\footnotetext{
${ }^{3}$ Unfortunately, the dataset does not contain quantitative data on the specific number of squatting cases, or the likelihood of eviction in these cases.

${ }^{4}$ In particular, landlords can provide incentives not to squat through the contract terms (e.g., by providing services to the tenants for the commercialization of their crops).

${ }^{5}$ Given that an alternative assumption might be that enforcement against squatting is only important for rich landlords renting to poor tenants, the empirical analysis will specifically test for such asymmetric effects.
} 
village communities in the Dominican Republic, as information sharing (gossiping) is an inherent part of social life. Furthermore, in the last 10 years, few new households have immigrated into the communities studied here. Studies in other parts of the world find that information on attributes of others is widely available in village communities (Bardhan, 1984; Bell, 1988; and Lanjouw, 1999).

Ackerberg and Botticini (2002) pointed out the importance of accounting for endogenous matching between landlords and tenants when analyzing land rental markets. They account for matching along one trait and instrument using regional differences reflecting the context. Relatively little empirical work has been done on matching accounting for more than one trait at the individual level. ${ }^{6}$ Two papers empirically estimate the individual determinants of matching in the marriage market to test Becker's (1973) assortative mating hypothesis. Jepsen and Jepsen (2002) estimate a conditional logit that models the matching process as a choice by one of the partners, determined by the absolute value of the differences in traits between the chooser and potential matches. It therefore corresponds to a one-directional decision process that does not account for utility maximization of the other side, nor for competition in the market. In large markets, the effect of such competition (i.e., the probability that your preferred choice is already matched with somebody else that he/she prefers) is likely to be negligible. There always exists another potential partner with (almost) the same characteristics who will be a close substitute for the most preferred match. But, in thinner markets, this might not be the case. Furthermore, partner selection differs from a discrete choice problem because the choice of a spouse is mutual and because different individuals cannot choose the same alternative. Suen and Lui (1999) explore a method that directly derives from the Becker model of efficient competitive matching in the marriage market, i.e., a matching process that maximizes marital output. This model has the advantage that it takes the reservation utility of potential partners into account, but does not allow including the non-chosen alternatives in the estimation.

In the local land markets that we consider here, many potential tenants end up not being matched to a landlord/plot. Our empirical specification is therefore based on a principal-agent model in which the landlord makes an offer to the tenant, and the tenant accepts or rejects. This modeling approach is justified by field observations that confirmed that it is the landlord who takes the first step and determines the terms of the contract. Competition among landlords comes through the reservation utility of tenants, as tenants that are wanted by many landlords will have a higher reservation utility. Hence, while our model is similar to Jepsen and Jepsen's in modeling the choice by one partner, it differs in accounting for the reservation utility of tenants and competition among landlords in the market. The model also incorporates the possibility of choosing not to match, and allows for matching along various characteristics.

\footnotetext{
${ }^{6}$ Most empirical work analyzing matching in the labor market estimates aggregate matching functions (explaining the number of matches in the labor market as a function of unemployment and vacancies), or individual transitions using panel data (see Petrongolo and Pissarides (2001) for an overview). Some work on marriage market matching also models individual transitions (Wong, 2003).
} 


\subsection{Theoretical model}

As few landlords in the dataset rent out more than one plot at a time, all landlord plot rental decisions are treated independently, and $i$ designates both a landlord and his plot. The landlord-tenant relationship can be thought of as emerging from a two-step decision process (Figure 1). The landlord decides whether to rent out plot $i$ or not and, if he chooses to rent, to which tenant $j$ to offer the contract. He also decides on the contract terms. In particular, he can offer the tenant a premium above his reservation utility to provide an incentive for non-squatting. Tenant $j$ then decides whether to squat, i.e., to stay on the land and continue cultivating without paying the rent, or not to squat. The probability of success in squatting depends on the plot's property rights security. Squatting entails a cost in the loss of benefits from future interactions, and this cost is higher for members of the same social class. If squatting is successful, the tenant de facto keeps the land in perpetuity. If squatting fails, however, the tenant has to pay the due rent and return the land.

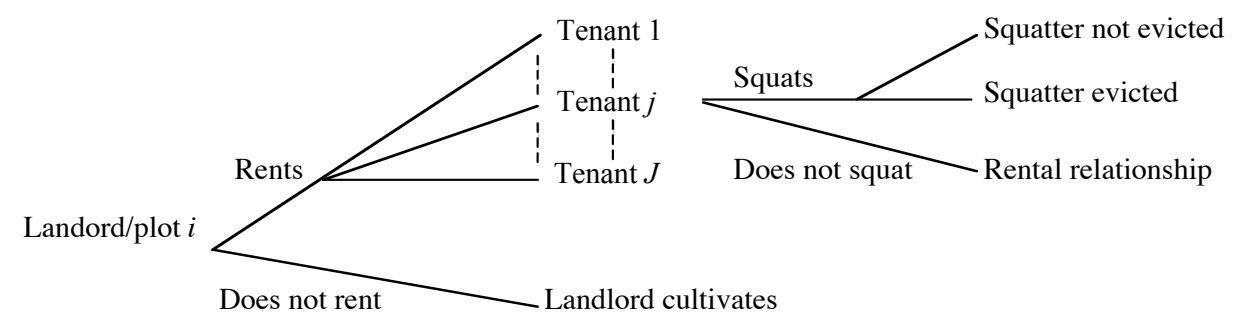

Figure 1. Landlord and tenant decisions and possible outcomes

Let $\pi_{i j}$ be the return to land obtained when plot $i$ is cultivated by tenant $j$, and $\bar{\pi}_{i}=\max _{j} \pi_{i j}$ the maximum return across potential tenants. Under direct cultivation, the landlord can earn $\pi_{i 0}$. In the case that $\pi_{i 0}<\bar{\pi}_{i}$, optimal efficiency in land use would be that plot $i$ be cultivated by tenant $j$ that maximizes $\pi_{i j}$. Under a well functioning land market with enforceable property rights, the landlord would obtain $\bar{\pi}_{i}=\max _{j} \pi_{i j}$ in perpetuity. ${ }^{7}$

With weak property rights that leave open the possibility of squatting, the landlord may however decide to rent to a tenant who produces a lower return to land $\left(\pi_{i j}<\bar{\pi}_{i}\right)$ but who is less likely to squat, or

\footnotetext{
${ }^{7}$ If markets were perfect, the landlord could also obtain this value through the sales market. Given existing imperfections in the credit market, we assume however that the sale option is not feasible for lack of access to credit by potential buyers. Furthermore, a landlord may prefer to rent and keep ownership of the family land asset, especially since buying well located land later could turn out to be difficult. Imperfections in the credit and land markets hence help explain the inefficiencies analyzed in this paper.
} 
he may even decide not to rent at all, generating inefficiency. To show this result, we first solve for the tenant's decision, which will be anticipated by the landlord.

\section{The tenant's decision to squat}

Each tenant $j$ has an opportunity cost $w_{j}$ outside the rental market. By squatting, the tenant loses

the benefit of future interactions $R\left(\Delta_{i j}\right)$, that we assume to depend on the social distance $\Delta_{i j}$ between the landlord and the tenant. If squatting is successful, the tenant keeps access to the plot of land, with net return $\pi_{i j}$ in perpetuity. If squatting fails, however, the tenant has to pay the rent $\pi_{i j}$ and return the land, and is de facto barred from the rental market, which leaves him with an income equal to his opportunity cost $w_{j}$ from then on.

The expected return $U$ to a tenant who decides to squat $\left(s_{i j}=1\right)$ is thus:

$$
E\left(U \mid s_{i j}=1\right)=\frac{1}{1-\delta}\left(w_{j}-R\left(\Delta_{i j}\right)+\operatorname{pr}\left(S_{i}=1\right) \pi_{i j}\right)
$$

where $\operatorname{pr}\left(S_{i}=1\right)$ is the probability that squatting on plot $i$ is successful, and $\delta$ the discount factor.

Landlord $i$ can choose to offer the tenant a premium $t_{i j}$ above his opportunity cost if he does not squat. In this case, the tenant receives $w_{j}+t_{i j}$. With an expectation of continuation of the contract and premium for not squatting, the tenant's decision to squat is expected to be the same every year, and hence either he squats the first year or never squats. The expected return under no squatting $\left(s_{i j}=0\right)$ is thus:

$$
E\left(U \mid s_{i j}=0\right)=\frac{1}{1-\delta}\left(w_{j}+t_{i j}\right)
$$

Assume some unobserved idiosyncratic heterogeneity in the disutility from squatting $\varepsilon_{j}$ in addition to these economic returns. The tenant's optimal decision is thus to:

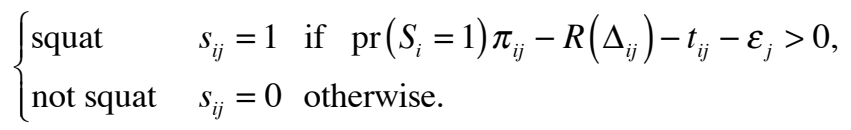

\section{The landlord's decision to rent out and the choice of tenant}


We assume that the landlord knows the distribution of the idiosyncratic disutility from squatting for potential tenants, but not individual values. ${ }^{8}$ Denoting $F($.$) its cumulative function, the landlord's$ appreciation of the risk that tenant $j$ may squat on his plot $i$ is given by:

$$
\operatorname{pr}\left(s_{i j}=1\right)=F\left(\operatorname{pr}\left(S_{i}=1\right) \pi_{i j}-R\left(\Delta_{i j}\right)-t_{i j}\right)
$$

Knowing the squatting risk and productive capacity of all potential tenants, the landlord can proceed to compare alternative rental contracts.

If the landlord rents to a tenant that does not squat, the contract is expected to last over an infinite time horizon, providing annual utility $\left(\pi_{i j}-t_{i j}\right)$. If the landlord rents to a tenant that successfully squats, he loses his land in perpetuity. But if the landlord is successful in evicting a squatting tenant, he can reconsider whether to rent or not the next period. The landlord's utility for renting out plot $i$ to tenant $j, V_{i j}$, is thus:

$$
V_{i j}=\left(1-\operatorname{pr}\left(s_{i j}=1\right)\right) \frac{1}{1-\delta}\left(\pi_{i j}-t_{i j}\right)+\operatorname{pr}\left(s_{i j}=1\right)\left(1-\operatorname{pr}\left(S_{i}=1\right)\right)\left(\pi_{i j}+\delta V_{i,-j}\right)
$$

where $V_{i,-j}$ is the maximum expected utility that the landlord can expect either from attempting to rent his land to another tenant from the pool or not renting it.

The landlord can also choose not to rent his land, obtaining an annual return $\pi_{i 0}$ from direct cultivation. With no expected change in conditions on the rental market, expectation is that if he does not rent the first year he never will. His utility is thus:

$$
V_{i 0}=\frac{1}{1-\delta} \pi_{i 0}
$$

The landlord's problem consists in deciding to rent out or not, and if he decides to rent, in choosing $j$ and the premium to offer this tenant in order to maximize expected utility from plot $i$ :

$$
\max _{j=0,1, \ldots, J} V_{i j}
$$

This can be solved in three steps. First, the landlord defines the optimal premium $t_{i j}$ to give any potential tenant $j$, should he decide to offer him a contract. This is the solution to maximizing (3). The first order condition for $t_{i j}$ gives:

\footnotetext{
${ }^{8}$ Hence there is some asymmetric information, but - in contrast with most of the labor literature - it cannot be reduced through a costly search.
} 


$$
\frac{d V_{i j}}{d t_{i j}}-\frac{1}{1-\delta}\left(1-\operatorname{pr}\left(s_{i j}=1\right)\right)+\left[\left(1-\operatorname{pr}\left(S_{i}=1\right)\right)\left(\pi_{i j}+\delta V_{i,-j}\right)-\frac{1}{1-\delta}\left(\pi_{i j}-t_{i j}\right)\right] \frac{d \operatorname{pr}\left(s_{i j}=1\right)}{d t_{i j}}=0,
$$

where the probability of squatting $\operatorname{pr}\left(s_{i j}=1\right)$ is given in (2). This shows that the optimal premium $t_{i j}$ and the probability of squatting are a function of the plot characteristics, through the terms $\operatorname{pr}\left(S_{i}=1\right), \pi_{i j}$, and $V_{i,-j}$, of the productivity of the tenant through the term $\pi_{i j}$, and of the social distance between landlord and tenants through $R\left(\Delta_{i j}\right)$. It also depends on the quality of the rest of the pool of tenants through $V_{i,-j}$. Denote by $Z_{i}$ the physical plot characteristics (e.g., plot size, irrigation) and by $T_{j}$ the tenant skill that positively affect profit $\pi_{i j}$. Total differentiation of (6) with respect to $t_{i j}$ and the variables $\operatorname{pr}\left(S_{i}=1\right), Z_{i}, T_{j}, R\left(\Delta_{i j}\right), V_{i,-j}$ indicates the direction of the influence of these variables on the optimal premium. Neglecting the second derivative of $F$ with respect to its argument, which has to be of secondorder of magnitude, one can show that $t_{i j}$ is an increasing function of $\operatorname{pr}\left(S_{i}=1\right)$ and of the land and tenant characteristics that positively affect $\pi_{i j}$, and a decreasing function of $R\left(\Delta_{i j}\right) .{ }^{9}$ This solution illustrates the tradeoff for the landlord between giving a large premium and the risk of squatting. Plots with higher productive values (higher $Z_{i}$ ) and weaker ability to enforce property rights (higher probability that squatting will be successful) garner a higher premium to the tenant, and tenants with lower cost to squatting $R$ are offered a higher premium to counteract their incentive to squat. The lower the quality of the rest of the pool of potential tenants (either from their skills or their social distances to the landlord) which affects the prospect of future earnings if the tenant was to squat, the higher the transfer to refrain him from squatting.

Second, the landlord decides to which tenant $j$ to rent, should he choose to rent his plot. This selection of tenant is made by comparing utilities under the different options, given the characteristics of each potential tenant and the optimal premium established in (6). Using the optimal premium in expression (3) shows that the landlord utility $V_{i j}$ from renting plot $i$ to tenant $j$ is clearly a decreasing function of social distance $\Delta_{i j}$ and an increasing function of tenant skill $T_{j}$ :

$$
\frac{d V_{i j}}{d \Delta_{i j}}=\frac{1}{1-\delta}\left(1-\operatorname{pr}\left(s_{i j}=1\right)\right) \frac{d R}{d \Delta_{i j}}<0
$$

\footnotetext{
${ }^{9}$ [Appendix for referee may go here]
} 
and $\frac{d V_{i j}}{d T_{j}}=\left[\left(1-\operatorname{pr}\left(S_{i}=1\right)\right) \frac{1-\delta \operatorname{pr}\left(s_{i j}=1\right)}{1-\delta}\right] \frac{d \pi_{i j}}{d T_{j}}>0$.

In his choice among potential tenants, a landlord may thus have to weigh their productive skills against their social proximity that would discourage them to squat. This is reinforced by the premium calculated in step 1, as larger social distances (associated with lower costs of squatting) lead to higher premiums. Hence both mechanisms increase landlords' incentives to choose tenants with whom they have stronger ties. ${ }^{10}$

Third, the landlord decides whether to rent out his land to or keep it under direct cultivation, comparing the highest utility he could derive from renting to the tenant optimally selected in step 2 , $\max _{j=1, \ldots, J}\left(V_{i j}\right)$, and the utility under direct cultivation, $V_{i 0}$.

Under secure property rights, by definition, the probability that squatting succeeds is null, $\operatorname{pr}\left(S_{i}=1\right)=0$. It follows that the probability that a tenant chooses to squat is also null, $\operatorname{pr}\left(s_{i j}=1\right)=\operatorname{pr}\left(-R\left(\Delta_{i j}\right)-t_{i j}-\varepsilon_{j}>0\right)=0$. Landlords have therefore no need to offer any premium, $t_{i j}=0$, and they would choose the tenant whose productive skill provides maximum return to their land as $V_{i j}=\frac{1}{1-\delta} \pi_{i j}$. The choice of whether to rent or not would thus boil down to comparing $\max _{j=1, \ldots, J} \pi_{i j}$ to $\pi_{i 0}$. The rental market allows the land to be cultivated under the arrangement that leads to the highest return.

This illustrates the source of inefficiency that results from insecure property rights. Under insecure property rights, a landlord may not select the tenant that would be the most productive on his plot, in favor of a tenant with whom he is more closely socially linked in order to limit the risk of squatting. This may, in turn, substantially reduce the benefit of renting land out. The outcome is a smaller sized and more segmented land rental market than would be optimally efficient. How much efficiency is lost in that rental market depends on the joint distribution of productive skills and social proximity to landlords of potential tenants. ${ }^{11}$ If landlords can't find productive tenants among those with whom they have close social relationships, the efficiency loss may be high. Note that this efficiency loss occurs despite the fact that there is no transaction cost, i.e., no "burned" resources in search or enforcement costs. It is only due to segmentation of the rental market that derives from heterogeneity of property right security across landlordtenant pairs.

${ }^{10}$ This also implies that the predictions of the model do not change for cases in which landlords are unable to offer a premium.

${ }^{11}$ In the empirical part of the paper, we report on an aggregate measure of efficiency by considering the extent to which the rental market equalizes land-labor ratios and use of machinery in local land markets. 


\subsection{Empirical specification}

Assuming a linear approximation for the utility functions, we write:

$$
V_{i j}=X_{i j} \beta+X_{i 1} \alpha_{1}+\mu_{i j} \equiv V_{i j}^{*}+\mu_{i j}
$$

and $\quad V_{i 0}=X_{i 0} \alpha_{0}+\mu_{i 0} \equiv V_{i 0}^{*}+\mu_{i 0}$,

where $X_{i j}$ are variables that characterize either the tenant or the tenant-landlord pair in (3), $X_{i 1}$ and $X_{i 0}$ are variables that characterize the landlord/plot in expressions (3) and (4), respectively, and $\mu_{i j}$ and $\mu_{i 0}$ are terms unobserved to the econometricians.

Elements of $X_{i 0}$ include the determinants of the return to land when managed by the landlord alone, $\pi_{i 0}$, i.e., the characteristics of the plot itself and the landlord's productive assets. Elements of $X_{i 1}$ include the landlord and plot characteristics that affect the return $\pi_{i j}$, the value of the plot in rental $V_{i-j}$, and the probability that the landlord will be able to defeat an attempt by the tenant to squat $\left(1-\operatorname{pr}\left(S_{i}=1\right)\right)$. Elements of $X_{i j}$ include variables that affect $\pi_{i j}$ and the probability of squatting $\operatorname{pr}\left(s_{i j}=1\right)$. They correspond to the productive assets of the tenant, possibly some interaction between the assets of the tenant and the landlord/plot that might affect the return to land, the social distance between the landlord and the tenant that affect the probability of squatting, and its interaction with the plot characteristics and its formal and informal property rights.

We assume that the vector $\mu_{i}=\left(\mu_{i 0}, \mu_{i 1}, \ldots, \mu_{i J}\right)$ follows a Generalized Extreme Value distribution, with the alternative choices grouped into two sets, $\{0\}$ for not renting out, and $\mathfrak{I}=\{1, \ldots, J\}$ for renting to any potential tenant available to $i$. This leads to a nested logit model, which corresponds to the landlord's decision depicted in Figure 1.

The model is written:

$$
P\left(V_{i j}=\max _{k=0, \ldots, J} V_{i k}\right)=\frac{e^{X_{i j} \beta}}{\sum_{k \in \mathfrak{S}} e^{X_{i k} \beta}} \frac{e^{\lambda I_{i}+X_{i} \alpha}}{e^{\lambda I_{i}+X_{i} \alpha}+1}, \text { for } j \in \mathfrak{I},
$$

and $\quad P\left(V_{i 0}=\max _{k=0, \ldots, J} V_{i k}\right)=\frac{1}{e^{\lambda I_{i}+X_{i} \alpha}+1}$, for $j=0$, 
where $I_{i}=\ln \left(\sum_{k \in \mathfrak{I}} e^{X_{i k} \beta}\right)$ is the inclusive value that summarizes the characteristics of all potential tenants for landlord $i, X_{i}=\left\{X_{i 0}, X_{i 1}\right\}$, and $\alpha=\alpha_{1}-\alpha_{0}$.

The model can be decomposed into two logit models. In the lower level model, the conditional choice among tenants for a landlord that would rent $\left(d_{i}=1\right)$ follows a conditional logit model. The probability that a landlord chooses tenant $j$ for his plot $i\left(d_{i j}=1 ; d_{i k}=0, \forall k \neq j\right)$ is:

$$
P\left(d_{i j}=1 \mid d_{i}=1\right)=\frac{e^{X_{i j} \beta}}{\sum_{k \in \mathfrak{I}} e^{X_{i k} \beta}} .
$$

Note that this expression does not include any landlord/plot characteristics $X_{i 1}$ separate from its interaction with the tenant characteristics. This is because terms that affect the return to land with any tenant cancel out in the landlord choice of tenants, conditional on the decision to rent out.

In the upper level model, the landlord chooses among the alternative of renting out $\left(d_{i}=1\right)$ and not renting out, following the logit model:

$$
P\left(d_{i}=1\right)=\frac{e^{\lambda I_{i}+X_{i} \alpha}}{e^{\lambda I_{i}+X_{i} \alpha}+1} .
$$

Whether to rent out or not depends on the landlord's characteristics $X_{i}$ that affect the return to land under tenancy or in independent exploitation and on the utility that could be derived from putting the land in tenancy, given the available choice of tenants, as summarized by the inclusive value $I_{i}$.

\section{Data and econometrics}

\subsection{The data}

An indirect survey approach was used to obtain data on communities and on each household and each plot within these communities. The indirect approach relies on the fact that a lot of private information is public at the level of the community. Hence, selected informants from the community can be used to answer questions about private matters of individual community members that are locally public knowledge. A similar approach has recently been used to study land market activity by Bardhan and Mookherjee (2008). Data collection started with a census of all 2523 households in 18 communities, and a census of all the plots that they own, rent-in, and rent-out. This information allows classification of households into 366 landlords, 465 tenants, and 1692 other households. The data set for the analysis 
consists of information on all landlords, all tenants, and 910 other households randomly sampled by community. For those households that do not rent land to others, we know whether they would like to rent land from others (or rent more land than they currently do) under the most common contract in the community. This allows us to control for the demand side in the estimation. The information is used to define the potential tenants (525 households out of the 910 households not currently engaged in the tenancy market), in addition to the 465 actual tenants. The number of potential tenants varies from 13 to 146 across the communities. The set of potential landlords consists of all land-owning households, whether they currently participate or not in the land rental market. Together they own 737 plots, of which 316 are rented out to community members. ${ }^{12}$ A substantial share of the plots $(43 \%)$ is rented out to family members. This may in part be because many households in these communities are related with each others (48\% of the landlords report that they have a lot of family in the community). The presence of family can be important both because it facilitates finding a tenant who is a family member and hence more trusted, and because family can help with the enforcement of one's ownership rights in case a non-related tenant decides to squat on the land. While we cannot separate out these effects from each other, we will use the presence of family as an indicator of informal property rights, and hypothesize that it will lead to less assortative matching by social class.

A short community questionnaire was used to gather data about the history of land conflicts in each of the communities, including those that involved absentee owners. This information was complemented with extensive qualitative interviews that allow to characterize the nature and history of land invasions and squatting. While actual cases of squatting are relatively rare, concerns about squatting were often mentioned as the first issue landlords considered when selecting their tenant. ${ }^{13}$ Many landlords noted that they were afraid of renting out, as a number of recent squatting cases had gone to court, and - after lengthy procedures - the courts had decided that landlords had to give part of the land to the tenants or pay

\footnotetext{
${ }^{12}$ In addition to the plots rented out to community members, there are 163 plots that are owned by households living in the community but rented out to households from other communities. Most of these plots are located on the outer limit or outside the community. These plots are excluded from the analysis as the data does not contain information about the characteristics of the tenants using these plots, or about the informal property rights on those plots. The landlords of these plots have however similar characteristics to those of the plots rented to community members, and the formal property rights on these plots are also similar. By excluding these plots, the empirical results are only representative for rental transactions within local markets. In particular, the results of the paper shed light on how property rights insecurity contributes to a segmentation of the land rental market among households living in the same communities. To the extent that these other plots are rented to neighboring community members, it is likely that similar forces apply to these other rental contracts, but one cannot exclude that landlords rely on different enforcement mechanisms in the presence of property rights insecurity.

${ }^{13}$ For example, one landlord noted that when her regular tenant of three years decided not to rent her land anymore she felt that this was the "biggest pain somebody could have given her", and her main concern was "how to find another person whom I can trust", given that she could not afford to lose the land as it was all she had to fall back on "for when I'm dying".
} 
them a monetary compensation. These were all cases of relatively rich landowners renting to relatively poor tenants. Interestingly, many poor tenants or landless people explained that the reason why rich landlords did not rent out to them was because "sometimes, we, the poor people, don't behave that well". Many informants noted that in the case of poor landowners renting out to poor tenants, such concerns were much less salient as the community would tend to solve these problems internally in favor of the poor landlord.

The communities are located in two regions that have similar characteristics. Constanza is located in a fertile valley in the mountainous area at the center of the country (La Vega province). It is characterized by very intensive irrigated horticultural production, which depends to a large extent on hired labor. San Francisco de Macoris is located in the flatlands of the Cibao region (Duarte province). Agricultural production consists mainly of rice (therefore referred to in this paper as the rice region). These regions are not meant to be nationally representative, but were selected because they have labor-intensive agricultural production where rental markets might lead to efficiency gains. Both regions have mainly seasonal crops, relatively intensive agricultural production with high input use (fertilizer, pesticides, and labor), and multiple crops per year. A substantial share of agricultural production is commercialized, agricultural income is an important part of the households' budgets, and in both regions there is excess demand for land. In the rice region, the land reform of the 60 s played a larger role. Nevertheless, land ownership inequality remains high in both regions, with community-level land Gini coefficients ranging from 0.63 to 0.94 , and the cumulative share owned by the $10 \%$ largest holders is on average $80 \%$.

The dataset contains information on demographic characteristics of the household, and characteristics of all the plots that they own or rent from others. In addition, the informant was asked to assign each household to one of four possible living standard categories: "very low", "low", "regular", and "high". To obtain a measure of class, the informants were instructed explicitly not to consider the productive assets of the households to judge their living standard. Instead it was agreed that they should be considering broad indicators of consumption or expenditures such as characteristics of the house, food consumed, health care, transportation means, and the level of education of the children. ${ }^{14}$ Because few households were categorized as "very low", we consider the "very low" and "low" living standards together as one category.

Landlords and tenants clearly differ by the amount of land they own. Landlords own on average 1.6 plots on 2.27 ha, while tenants own 0.3 plots on 0.3 ha. Landlords and tenants do not correspond however to dramatically different welfare classes, as can be seen in Table $1.33 \%$ of the landlords are from

14 The living standard measure was regressed on these indicators, which shows strong correlations. Productive assets (land, education, etc.) are not significant, once the other factors are controlled for. This shows that informants indeed considered welfare measures, as opposed to measures of productive assets, when categorizing the different households. 
the lower class, $39 \%$ from the intermediate, and $28 \%$ from the higher class, while those numbers are $29 \%$, $43 \%$, and $27 \%$ respectively for tenants. ${ }^{15}$

Combining each actual landlord-plot with its corresponding potential tenants from the same community gives almost 24,000 potential matches. The variables used in the estimations are the following:

- Plot characteristics that affect production $\left(x_{i}^{p}\right)$ are the plot size, and a dummy for whether the plot has irrigation potential measured by the proximity to an irrigation canal or natural stream.

- Landlord's and tenant's productive characteristics and assets $\left(z_{i}, z_{j}\right)$ are the gender, age, and education of the household head, the number of adult household members, and machinery ownership characterized by two dummy variables for owning any machinery and owning a lot of machinery. In addition, we consider for landlords the area they own and for tenants the number of other plots they are cultivating as an indicator of their opportunity cost. Finally a dummy variable, "agricultural engineer", identifies the few households in which the head owns a lot of machinery and has a university degree.

- The social distance between the landlord and the tenant $\left(\Delta_{i j}\right)$ is captured by two dummy variables: one variable equaling 1 for matches between people with a regular and high living standard, or between people with a low and regular living standard; the other variable equaling 1 for matches between high and low living standards. ${ }^{16}$

- Plot/landlord characteristics that affect the probability that squatting will be successful $\left(x_{i}^{S}\right)$ are dummy variables for whether the plot has a title, which measures the formal strength of the property rights to the plot; whether the landlord has a lot of family in the community, which is a proxy for the informal strength of the property rights; ${ }^{17}$ and whether there were cases of land invasions during the last five years in the community, which also proxies informal property right strength. Finally, we include a regional dummy for the rice region, since it is a region with a long history of land reforms and related conflicts.

\footnotetext{
${ }^{15}$ As could be expected, landlords are on average older than tenants (58 years old compared to 43) and more likely to be female ( $29 \%$ of households renting out are female headed households, compared to only $6 \%$ for tenants).

16 The specification assumes that effects of low-regular and regular-high matches are similar, and that the effects of social distance are symmetric. Both assumptions were empirically tested and could not be rejected (see section 6).

${ }^{17}$ Specifically, it measures whether there are a lot of other households in the community that belong to the landlord's extended family (brothers, uncles, nephews, etc.).
} 
The explanatory variables $\left(X_{i j}\right)$ for the lower level model (7) include social distance $\left(\Delta_{i j}\right)$, interaction terms $\left(\Delta_{i j} x_{i}^{S}\right)$ to test the hypothesis that social distance matters more when the insecurity of property rights is higher, and tenants' characteristics $\left(z_{j}\right)$. Tenant characteristics affect the decisions of landlords both through their effect on the total expected profit and through their effect on the tenants' reservation utility, and as such can have offsetting effects on the landlord's net return $\pi_{i j}$. We also include some interaction terms $\left(x_{i}^{p} z_{j}\right)$ to account for the fact that tenant's endowments might be more important for cultivating large and irrigated plots. ${ }^{18}$

The explanatory variables $\left(X_{i}\right)$ for the upper level model (8) include plot's and landlord's characteristics $\left(x_{i}^{p}, z_{i}\right)$ and the insecurity of property rights variables $\left(x_{i}^{S}\right)$.

\subsection{Econometric issues}

While having a complete characterization of the land market presents a great advantage in terms of effectively observing the two sides of all matches and characterizing all opportunities offered for contracts, it does raise some econometric problems. In our sample, as in the real world of a community, potential tenants in a community consist of a finite number of persons who are common to all landlords of the community. Hence the unobserved terms $\mu_{i j}$ in equation (2) could be correlated across landlords $i$ if they contain some tenant $j$ 's unobserved characteristics. We will thus proceed with an estimation of the model with tenant fixed effects as an alternative to the estimation with tenants' characteristics.

The second econometric problem comes from a possible negative correlation between the terms $\mu_{i j}$ due to the fact that tenants do not cultivate more than a few plots. Hence if one landlord contracts with a given tenant, it reduces the probability that another landlord can contract with the same tenant. This creates a negative correlation across landlords' decisions for the same tenant. In the core estimation, we account for this competition by inclusion of a variable measuring the number of other plots the tenant is currently cultivating. This is motivated by the assumption that each landlord takes the decisions of the tenants and of the other landlords as given. Inclusion of such a variable cannot be done with the tenant's

\footnotetext{
${ }^{18}$ In addition, $\pi_{i}$, and hence the matching between landlords and tenants, could potentially depend on the complementarities or substitutability between the productive asset endowments of the landlord and the tenant, in line with Becker's theory of assortative matching in the marriage market. E.g. landlords with low labor endowments might prefer tenants with high labor endowments, or vice versa. We therefore test for interactions between landlord and tenant's assets in section 6.2.
} 
fixed effects model because of collinearity, and hence the fixed effect estimation gives consistent, but not efficient, results (McFadden, 1999).

Finally, as we used an indirect survey approach and relied on an informant to obtain the information for all the households of his community, one may suspect existence of an informant effect that could create correlation between the error terms of the observations from the same community. In the lower level model, an additive informant effect would not pose a problem since all potential tenants would have the same term that cancels out in their comparison. In addition, we check for robustness of the results allowing for correlation of observations obtained from the same informant. In the upper-level estimation, we check for the possibility of either correlated errors or an informant fixed effect.

\subsection{Identification}

Our model assumes that the variables used to measure informal and formal property rights are not correlated with possible unobserved factors that affect decisions on the land rental markets. This can be motivated by the specific choice of variables, the empirical specification, and the specific context in the regions of study. The presence of family is the first measure of informal enforcement. Immigration into these communities has been very limited. Landlords have on average lived 46 years in their community. The presence of family in the community is hence mostly a result of historical fertility and migration decisions of other households in the community, that can arguably be considered a given for landowners making decisions in the land rental markets. Land invasions, our second indicator, are measured at the level of the community, and reflect past large-scale conflicts. We only consider large-scale land invasions, rather than past individual cases of squatting, as the latter are endogenous to past equilibrium contract choices. In contrast, interviews with participants of the large-scale invasions revealed that these invasions were escalations of lingering conflicts between the community and large absentee landlords. Such conflicts, that involve the occupation of farms of absentee owners by large groups of peasants, were typically driven by historical tensions. They are very distinct from the individual squatting cases that landowners who live in the communities fear in the rental market. ${ }^{19}$ The positive correlation between assortative matching and land rental decisions when property rights are insecure is hence unlikely to reflect reverse causality and correlation over time. Past land invasions do, however, create general perceptions of property rights insecurity, which according to our model influence assortative matching in the land rental markets.

\footnotetext{
${ }^{19}$ The assertion that the prevalence of conflicts is not driven by current land market outcomes and related inequality within the community is supported by the very low correlation between the land Gini coefficient (measuring inequality between community members) and land conflicts in our dataset. We will also test the robustness of our results to inclusion of the land Gini coefficient (see section 6.2).
} 
The title status of a plot, that gives the measure of formal property rights, is determined mostly by a combination of historical factors: different property rights regimes installed by various former colonizing powers, the land reforms in the 1960s, and the year in which the plot was affected by the reform (beneficiaries of land that was expropriated in the early years of the land reforms received titles, others didn't). Hence, the title status of a plot is largely determined by different historical events that are beyond the control of current occupants. Note also that the variable indicates whether the plot has a title, not whether it is registered under the name of the owner. In fact, in many cases the titles are not updated to the current owner.

Given the cross-section nature of our dataset, there might remain endogeneity concerns. ${ }^{20}$ As there is no plausible instrumental variable approach for our data, we instead control for unobservables and test for robustness of the results. Our model specification implies in itself control for a number of unobserved effects: the lower level logit (equation 7) is a fixed effect model (i.e., a conditional logit), and hence all fixed plot level (and landlord and community level) unobservables are controlled for in all the matching regressions. We also present an estimation that includes tenant fixed effects. In the upper level logit we test for robustness of our results to inclusion of informant and community fixed effects. Furthermore, we show that our results are robust to inclusion of different sets of control variables and alternative specifications.

\section{Estimation results}

\subsection{Main results}

Estimation of the lower level logit (equation (7)) on the choice by a landlord of a particular tenant among potential tenants is reported in Table 2. The regressions were done on the 301 out of 316 rented plots for which we have data on both sides of the transaction. The first three columns establish the main result of the paper: landlords and tenants match assortatively by living standard status and the larger the social distance the less likely they are to match (col. 1). These results are robust to controlling for the tenant's characteristics (col. 2). Assortative matching, however, only takes place in communities that have experienced land invasions and is less likely for landlords with large numbers of family members in the community (col. 3). The effects are again stronger when social distance is larger. Hence, the presence of conflicts reduces the likelihood of renting out to people whose living standard is different from one's own,

\footnotetext{
${ }^{20}$ In particular, it is possible that some current titles are the result of active efforts by landlords to obtain a formal title for their plot. It is unclear however in which direction this would bias the results. It could be, for instance, that more risk averse landlords obtained titles, but that they are also less likely to rent out or only rent to people with similar living standard. But it could also be that more entrepreneurial landlords obtained titles, and that once they have a title they are more likely to rent out, or to rent across living standards. Both mechanisms could be at work, but would affect the results in opposite directions.
} 
and the presence of family within the community increases the likelihood of renting out to people from a different living standard class. The presence of family in the community is likely to increase the possibilities of contract enforcement, both directly and indirectly: directly, because alternative enforcement mechanisms based on family ties might increase the likelihood of renting out to a family member, even if she is from a different socio-economic class. And indirectly because the presence of family members in the community can help landlords enforce contracts with third parties, as it increases the costs (loss of social benefits) of squatting for tenants. ${ }^{21}$ Interestingly, formal titling does not affect matching. This particular result might, however, be driven by lack of variation as many of the plots that are actually rented out have a formal title (85 percent).

Looking at tenants' assets and characteristics, landlords are more likely to rent out to households with more educated and male household heads, and with machinery. This suggests that the positive effect of productive assets on expected profit compensates the negative effect through the reservation utility. However, landlords are less likely to rent out to tenants who already cultivate more other plots, which is consistent with competition between landlords raising the reservation utility of the tenants.

In column 4, we report a regression with interaction effects between plot and tenant characteristics. Among the many potential interactions, we have only kept those that are consistently significant across the different possible specifications. They show that endowments of machinery and education are more important for larger plots, and large families are an advantage for renting in plots with irrigation potential. From our field experience, the latter is related to the fact that irrigation allows for labor and capital-intensive cultivation, and large households can provide either supervision and/or a source of cash flow for purchasing inputs. Overall these interaction effects are consistent with the hypothesis that the landlord faces a trade-off between the positive effect of a tenant's assets on expected profit and the negative effect on reservation utility, as a tenant's assets make him more likely to get matched with plots of higher productive potential.

The key results are robust to introduction of an informant cluster effect (col. 5). The next column shows a specification excluding variables that are not robustly significant, except for those that also enter with interaction effects, which will be used for the calculation of the inclusive value and the simulations. ${ }^{22}$ The last column reports results of the estimates with tenant fixed effects. In this estimation, the set of potential matches for each landlord is restricted to the actual tenants in the community since the fixed effects cannot be identified for the households that do not rent from any landlord. Results show that the

\footnotetext{
${ }^{21}$ Because we do not have information about the family ties between each landlord and each potential tenant, we cannot distinguish between the direct and the indirect effect.

22 The interaction effects with the regional dummy are, though insignificant, also included in this specification, to keep controlling for regional differences.
} 
effect of informal property rights strength (family protection and land invasions) on matching between high and low living standard classes is robust to including the fixed effects.

Estimation results for the upper level logit (equation (8)) for the choice of a landlord to rent out are reported in Table 3. The regression was done on the 700 out of 737 plots for which we have complete data. The first column reports the core estimation, the second column reports results with informant fixed effects, and the third column the results allowing for correlation across observations from the same informant in both estimation levels. As expected, the inclusive value (derived from the estimation reported in Table 2, col. 6), measuring the average utility the landowner can expect from the potential tenants in his community, has a positive effect on the decision to rent out. A title on the plot has a positive effect on the probability that it be rented out, controlling for the matching. Past land conflicts and family protection have, however, no direct effect, but only an indirect effect through their influence on the average expected utility of a match. In the last column, we estimate a simplified model to be used in the simulation, taking out variables that are not consistently significant or that are potentially endogenous to the choice of renting out (engineer and number of active adults in the household).

\subsection{Robustness checks}

The hypothesis of positive assortative matching in our model implies that landlords of all classes prefer renting to tenants from their own socio-economic class if property rights are insecure. One could alternatively hypothesize that the probability of squatting would be higher for poor tenants, and that both rich landlords and poor landlords would avoid renting to poor tenants when property rights are insecure. Such a mechanism could provide an alternative explanation for the empirical findings presented above. We therefore test this hypothesis explicitly by replacing the social distance variables with the tenant's class. The second column in Table 4 shows that, while tenants with low living standards have a lower overall probability of being chosen (possibly because poor tenants tend to have less productive assets), none of the interaction effects of a tenant's class with the property rights variables are significant. Hence, we do not find empirical evidence for the alternative hypothesis, supporting our original interpretation of assortative matching because of property rights insecurity.

A related concern might be that, by measuring the social distance as an absolute value of the difference between landlord and tenant characteristics, we have assumed that the effect of social distance is independent from the direction of the difference. To test whether property rights insecurity only restricts renting from rich landlords to poor tenants, or also in the reverse direction, the model was also estimated allowing the coefficient of the interaction terms with the property rights variables to differ depending on the direction. Column 3 shows that the results of our base variables are robust to the specification in which 
additional variables were added to allow for these asymmetric effects. The hypothesis that the coefficients of the interaction effects with property rights are independent of the direction of the difference cannot be rejected. The P-value of the joint F-test of the variables capturing possible asymmetric effects is 0.61 .

Finally, the assumption that low-regular matches and regular-high matches have the same effects was tested by including separate variables allowing the coefficients to be different. Again, we cannot reject that the coefficients of these dummies were significantly different for any of the interaction effects, the Pvalue of the joint F-test if 0.37 , and the key results are robust (column 4). Hence, overall, the robustness checks indicate that property rights insecurity leads to similar assortative matching by social distance in all classes, consistent with the theoretical model.

In addition to property rights insecurity, matching between landlords and tenants might also be driven by other factors. The evidence in Table 2 suggests that it depends in part on interactions between the plot and tenant characteristics. But it could potentially also depend on the complementarities or substitutability between the productive asset endowments of the landlord and the tenant, in line with Becker's theory of assortative matching in the marriage market. We therefore estimated a model that controls for differences in asset endowments between landlords and tenants (age, labor, machinery, and education). Column 5 shows that there is some evidence for such interactions between landlord and tenant characteristics. More importantly, the relationship between property rights and social matching is robust in this alternative specification.

A different type of concern could arise from the use of key informants, i.e., that informant characteristics themselves could be causing an omitted variable problem. We therefore present results that control for an interaction effect between the informant's living standard and the landlord-tenant social distance variables (Table 5, column 2) and for the difference between living standards of informants and tenants (column 3 ). ${ }^{23}$ These variables are not significant and results remain robust. Results of the upper level model are also robust to inclusion of dummies indicating the social distance between informant and landowner or the living standard class of the informant itself. Hence we do not find evidence of significant effects of the informant variables, which reduces concerns related to possible informant bias.

Next, because there are some communities for which there was more than one informant, and because it might be important to allow for clustering of standard errors at the community level, we also estimate the regressions allowing for clustering of standard errors by community (column 4). In the upper level model, we estimated specifications with a community (instead of an informant) fixed effect, and

\footnotetext{
${ }^{23}$ The class of the informant and any other fixed informant characteristics are further controlled for through the fixed effect.
} 
specifications allowing for clustering at the community level. We find that controlling for community-level correlation does not affect the results.

Another potential concern related to our empirical model is the use of the variable measuring the number of other plots to capture competition among landlords. While this variable is exogenous to each individual landlord, one could argue that it is determined in the local market together with the matches we analyze. Column 5 shows that excluding this variable from the regression does not affect our main results. Indeed in the model that included the tenant-fixed effects, this variable was also excluded. The results are also robust to alternative characterizations of the effect of landlord competition on the reservation utility of the tenants, using either total amount of other land cultivated (column 6) or the total amount per capita (column 7).

In the estimations, we have pooled plots with different types of contracts. Specifically, of the 302 plots that are rented to other community members, 186 are rented under a sharecropping contract, 48 under a fixed rent contract with payment in cash, and 62 under a fixed rent contract with payment in labor services. The dominance of sharecropping contracts and the relatively small number of observations prevent us from analyzing the contract choice together with the partner and rental choice decisions. Nevertheless, as a robustness test, we estimated the partner choice when including only the plots in sharecropping (column 8). The results are robust for this subset of plots, even if precision is less due to the smaller number of observations. This suggests that differences between contract types are not driving our results.

Our regression results are also robust to including interactions between social distance variables and the land Gini coefficient (column 9). This indicates that the differences in the prevalence of conflicts seem to be related to other factors (such as history of land reform, social cohesion, etc.) rather than to differences in current land access inequalities. This might be due to the fact that land inequality is high in all the communities. And finally, the results are robust to including further interactions between the social distance variables and all the tenant characteristics (column 10). Similarly, results are robust to including interactions between the social distance variables and landlord characteristics.

\section{Effects of security of property rights and capital endowments on market size, efficiency, and equity}

To show the importance of property rights on market size, efficiency, and equity, the estimated model is now used to simulate the extent to which strengthening both formal and informal property rights affects these outcomes. We also simulate the importance of access to working capital for tenants on these outcomes. 


\subsection{Simulation of the land rental market}

Simulation of the market equilibrium is done for each community separately, with an iterative procedure that accounts for competition in the market. The iterative process simulates what is in fact a simultaneous process with full information.

Each simulation is defined by a set of values given to the property rights or asset variables. We start with a baseline simulation, which uses the observed characteristics of tenants and plots and the estimated parameters to produce a predicted rental market equilibrium. The purpose of this baseline simulation is to validate the simulation model by comparing the predicted to the observed rental market equilibrium and then to serve as the benchmark to which simulated markets are compared. We now describe how each simulation is performed.

We first predict for each plot $i$ the probability of being rented out, $P\left(d_{i}=1\right)$, applying the coefficients in Table 3, col. 4 to the characteristics of the plot (including in particular the titling status as specified by the simulation) and the inclusive value, which measures the value a landlord can expect from matches with tenants in his community. The inclusive value in turn is calculated based on the estimated coefficients in Table 2, column 6, with $I_{i}=\ln \left(\sum_{k \in \mathfrak{I}} e^{X_{i k} \beta}\right)$ and $X_{i k}$ representing characteristics of the tenant or the tenant-landlord relationship (including in particular the family relationship and land invasion variables as specified by the simulation). ${ }^{24}$

One complication for the simulation exercise comes from the fact that we do not observe all the plots and potential tenants, but a sample of them, each with a sampling weight that comes from the sampling design. Consider then a community with $I$ sampled landlord-plots $i \in I=\{1, \ldots, I\}$, each with a sampling weight $\omega_{i}$, and $J$ sampled tenants $j \in J=\{1, \ldots, J\}$, each with a sampling weight $\omega_{j}$. The full land rental market thus includes $I^{*}=\sum_{i} \omega_{i}$ landlord-plots and $J^{*}=\sum_{j} \omega_{j}$ tenants. The market is modeled as working in successive rounds of offers from landlords. In the first round, each landlord-plot makes one offer, selecting the tenant $j$ with the highest conditional probability $P\left(d_{i j}=1 \mid d_{i}=1\right) .{ }^{25}$ In the illustration given in Figure 2, for example, landlord $i 1$ selects tenant $j 1$, while landlords $i 2$ and $i 3$ select tenant $j 2$. The tenant only accepts the offer that maximizes $P\left(d_{i}=1\right) P\left(d_{i j}=1 \mid d_{i}=1\right)$, i.e., the tenant exercises his options in choosing the landlord-plot with which he has the highest probability to match. The

\footnotetext{
${ }^{24}$ As such, we can also separately quantify the indirect effects that come from the value to be expected on the rental market and the direct effects of property rights insecurity.

${ }^{25}$ In the utility framework, this implies that the tenant will only accept a match that maximizes total utility.
} 
probability that the match effectively occurs $P\left(d_{i j}=1\right)$ is computed as the product of the probability that a given plot is rented out $P\left(d_{i}=1\right)$ and the conditional probability of the match $P\left(d_{i j}=1 \mid d_{i}=1\right)$. The number of effective matches $\omega_{i j}$ corresponding to a sample match $i j$ is the minimum between the number of landlord-plots $\omega_{i}$ and the number $\omega_{j}$ of tenants $j$. Hence, after the first round matches are settled, each sample match $i j$ leaves either some landlord plots $\omega_{i}-\omega_{j}$ not rented, if this number is positive, or some available tenants $\omega_{j}-\omega_{i}$ in the opposite case. ${ }^{26}$

\begin{tabular}{|c|c|c|c|c|c|}
\hline \multicolumn{3}{|c|}{ Landlord-plots } & & \multicolumn{2}{|c|}{$\underline{\text { Tenants }}$} \\
\hline$i$ & Weight & $\begin{array}{l}\text { Probability } \\
\text { to rent out }\end{array}$ & Landlord's first choice & Weight & $j$ \\
\hline$i 1$ & $\left(\omega_{i 1}\right)$ & $\hat{P}\left(d_{1}=1\right)$ & $\hat{P}\left(d_{11}=1 \mid d_{1}=1\right)$ & $\left(\omega_{j 1}\right)$ & $j 1$ \\
\hline$i 2$ & $\left(\omega_{i 2}\right)$ & $\hat{P}\left(d_{2}=1\right)$ & $\hat{P}\left(d_{22}=1 \mid d_{2}=1\right)$ & $\left(\omega_{j 2}\right)$ & $j 2$ \\
\hline & $\left(\omega_{i 3}\right)$ & $\hat{P}\left(d_{3}=1\right)$ & $\hat{P}\left(d_{32}=1 \mid d_{3}=1\right)$ & $\left(\omega_{j 3}\right)$ & $j 3$ \\
\hline & $\vdots$ & & & & \\
\hline
\end{tabular}

Figure 2. Simulation of the matching process

The market is then cleared of the matches that have been settled, and we repeat the process until all landlord-plots are matched to a tenant. ${ }^{27}$

The outcome of this procedure gives sample matches $i j$, each with a sampling weight $\omega_{i j}$. Note that, by construction, all landlord-plots $i \in I$ are matched to tenants, i.e., $\sum_{j} \omega_{i j}=\omega_{i} \cdot{ }^{28}$ Not all tenants $j \in J$, however, are necessarily chosen by a landlord. If $\sum_{i} \omega_{i j}>\omega_{j}$, then all tenants represented by sample tenant $j$ can have at least one plot in rental. But if $\sum_{i} \omega_{i j}<\omega_{j}$, then sample tenant $j$ is only partially matched in the tenancy market. It is easier to think about this by splitting $j$ in two tenants: tenant $j 1$, with sampling weight $\sum_{i} \omega_{i j}$ who has access to a rental plot, and tenant $j 2$, with sampling weight $\omega_{j}-\sum_{i} \omega_{i j}$ without a rental plot.

\footnotetext{
${ }^{26}$ In the first round, tenants will not accept an offer that implies a lower utility than a match with a landlord for whom he might be the second choice. Therefore, the results of the iterative process are the same than a process in which landlords would be allowed to go for their second choice in the first round (if their first choice was not feasible).

${ }^{27}$ Matched tenants stay available for additional matches but the number of plots they cultivate is updated after each match, which, because of the negative coefficient on that variable, decreases the likelihood of a future match. The number of matches is limited to the actual number of plots tenants rent for those who do not want to rent in more land, and not limited for the others.

${ }^{28}$ Note however that many of these plots might have a low probability to be rented out, which is accounted for in the simulation through $P\left(d_{i}=1\right)$ and which will be reflected in the aggregation (see 7.2).
} 


\subsection{Simulated effects of securing property rights and endowing tenants with capital}

Summary statistics reported in Table 6 are obtained by aggregating the simulated matches. Aggregation of landlord-plot characteristics $v_{i}$ (such as the total number of plots and area rented out) are calculated as:

$$
\sum_{i} P\left(d_{i}=1\right) \omega_{i} v_{i}
$$

Aggregation of tenants characteristics $v_{j}$ (such as the number of tenants and the number of poor tenants) are calculated as:

$$
\sum_{j} \min \left(\sum_{i} P\left(d_{i}=1\right) \omega_{i j}, \omega_{j}\right) v_{j}
$$

Finally, aggregation of matched landlord-tenant characteristics (such as area rented to poor tenant, landlabor ratio on plots rented by poor landlords) are computed as:

$$
\sum_{i} P\left(d_{i}=1\right) \sum_{j l i j \in M} \omega_{i j} v_{i} v_{j}
$$

Column 1 in Table 6 reports characteristics of the observed rented plots and tenants, and column 2 the characteristics of the simulated plots and tenants. We see that the simulations replicate relatively closely the observed situation. Column 3 simulates the matches that would occur if the property rights to all plots had been secure, i.e., if all plots had a full title, plots had as much security as with informal family protection, and there had been no past conflicts in any community. In rendering property rights secure, we contrast between the role of a title (column 4), and the role of enhancing protection and reducing land conflicts (column 5). Column 6 shows the joint effect of property rights security and providing working capital (machinery) to all tenants and column 7 the effect of providing working capital alone. We are interested in quantifying the efficiency and equity effects that can come from these interventions. Efficiency effects can come from two sources: expansion of the size of the land rental market, allowing landlords who wanted to rent to now do it; and allocative efficiency gains whereby the land/labor and machinery/plot ratios become equalized across poor and non-poor landlords and owners. Equity effects come from the extent of poor tenants' participation to the land rental market in both numbers and shares.

We see that increasing the security of property rights leads to a significant expansion of the size of the land rental market. With secure property rights (column 3), 21\% more plots are rented out and 13\% more households obtain access to rentals. Most of this gain is due to the increase in the inclusive value (the value a landlord can expect from matches with tenants in his community) that accompanies property rights security. 
The results also suggest that segmentation of the land rental market due to property rights insecurity leads to important allocative inefficiencies. With insecure property rights (column 2), the average land-to-labor ratio on plots rented out by the non-poor is substantially higher than on plots rented out by the poor (3.44 vs. 1.13). This suggests that labor might not be optimally allocated. The difference disappears once property rights are secure (3.11 vs 2.94) (column 3). ${ }^{29}$ The difference in availability of machinery (i.e., either the tenant or the landowner has machinery) between plots rented by poor and non-poor landlords also disappears. Securing property rights thus induces efficiency gains via convergence in allocative efficiency across plots rented out by landlords from different social classes.

Results also show that securing property rights has large equity effects by differentially benefiting the poor. The number of poor tenants increases by $59 \%$ and the number of plots rented out to poor tenants by $65 \%$. This gain is higher than proportional in their favor: the percentages of plots rented out to poor tenants increases from 29 to 40, and the percentage of poor among tenants from 35 to 50 .

Decomposing the instruments used to make property rights secure is revealing of which programs may create the greatest gains in this setting. Granting formal land titles increases the area rented to the poor by $11 \%$, while reducing land conflicts and enhancing land protection increases it by another $55 \%$ to $63 \%$. This suggests that titling programs as pursued by some donor agencies might only achieve high payoffs if accompanied by initiatives to help resolve conflicts and enforce the law. These latter programs have been much less present in efforts to strengthen property rights.

The last two columns show that a policy intervention that would provide not only secure property rights to landlords but also access to working capital to potential tenants would lead to a more equitable outcome on the land rental market. With secure property rights and access to capital, the number of plots rented to the poor increases by $180 \%$, and the area rented to the poor by $310 \%$. In fact, the poor would rent more than half of both plots and area in the market. Comparing these results with the effects of only providing working capital, we see that capital and property rights security have complementary effects on access to land for the poor. Interestingly, while in the current situation plots owned by non-poor landlords are much less intensively cultivated, the difference almost disappears with the combination of these two policies. ${ }^{30}$ Hence, policies that guarantee the security of property rights and enhance access to working capital for potential tenants reinforce each others in putting into place a larger, more efficient, and more equitable land rental market.

\footnotetext{
${ }^{29}$ The overall increase of the land/labor ratio with secure property rights is caused by the fact that there is a larger increase in the area rented than in the number of tenants.

${ }^{30}$ Land/labor ratio of landowner's plots were calculated by taking the weighted average of tenant's and landowner's land/labor ratio, with the probability of renting out constituting the weight. Tenant's and landowner's land/labor ratio were calculated using land cultivated by both after accounting for all matches and their probabilities.
} 


\section{Conclusions}

Analysis of the performance of land rental markets when there is insecurity of property rights, a widespread situation in developing countries, shows that insecurity can have high efficiency and equity costs, contributing to the reproduction of social inequalities. This happens when landlords' decision to rent decreases with social distance in fear that socially distant tenants are more likely to successfully squat on rented land. The efficiency cost arises if the landlord cannot find productive tenants among those with close social relationships. As a consequence, he will rent less, and he will have to choose less productive tenants. In the regions of the Dominican Republic analyzed here, we find that landlords are deterred from renting by lack of land title, more land invasions in the community, a history of land reform, and less family protection in the community. Equity costs also derive from social segmentation. With more insecurity, land rental transactions are confined to landlord-tenant pairs that have similar living standards.

The empirical results suggest that, for the regions studied, guaranteeing secure property rights is fundamental for improving market performance. Simulations show that it would increase the area rented and the number of rental transactions by $20-21 \%$. It would also improve allocative efficiency across plots, with convergence in land/labor ratios and in machinery used on plots rented by poor and non-poor landlords.

Greater security of property rights would increase access to land for the poor and their share of the land rental market. With security of property rights, the area and the number of plots rented to poor tenants would increase by $63-65 \%$, and their share of the land rental market would increase by $29 \%$ in area and $40 \%$ in number of plots.

Results also show that participation in the land rental market for the poor is constrained by lack of access to working capital. Simulations suggest that increasing both tenure security and the machinery endowments of tenants would increase the number of poor that get access to land through rental by $151 \%$ and the total area rented by the poor by $310 \%$.

Improved security of property rights can thus have substantial benefits not only for landowners, but also for those with whom they might interact in the rental markets. Formal land titling programs, reduction of land conflicts, and enforcement of property rights, complemented by greater access to capital for poor potential tenants, can be important instruments for the reduction of local inefficiencies, inequities, and stubbornly high inequalities. 


\section{References}

Ackerberg, Daniel, and Maristella Botticini. 2002. "Endogenous Matching and the Empirical Determinants of Contract Choice.” The Journal of Political Economy 110(3): 564-91.

Bardhan, Pranab. 1984. Land, Labor and Rural Poverty: Essays in Development Economics, New York: Columbia University Press.

Bardhan, Pranab, and Dilip Mookherjee. 2008. "Determinants of Redistributive Politics: An Empirical Analysis of Land Reforms in West Bengal, India," UC Berkeley and Boston University, mimeo.

Becker, Gary. 1973. “A Theory of Marriage: Part I.” The Journal of Political Economy 81(4): 813-846.

Bell, Clive. 1988. "Credit Markets and Interlinked Transactions.” In H. Chenery and T.N. Srinivasan, (eds.), Handbook of Development Economics, Amsterdam: North Holland, pp. 763-830.

Besley, Timothy. 1995. "Property Rights and Investment Incentives: Theory and Evidence from Ghana." The Journal of Political Economy 103(5): 903-37.

Bourguignon, Francois, and Christian Morrison. 2002. "Inequality Among World Citizens: 1820-1992." American Economic Review 92(4): 727-44.

Braselle, Anne-Sophie, Frederic Gaspart, and Jean-Philippe Platteau. 2002. "Land Tenure Security and Investment Incentives: Puzzling Evidence from Burkina Faso.” Journal of Development Economics $67(2): 373-418$.

Carter, Michael, and Juan Chamorro. 2001. "The Economics of Liberalizing Segmented Land Markets: Theory and Evidence from Nicaragua.” Paper presented at the AAEA meeting, August 2001, Chicago.

Carter, Michael, and Pedro Olinto. 2003. "Getting Institutions "Right" for Whom? Credit Constraints and the Impact of Property Rights on the Quantity and Composition of Investment." American Journal of Agricultural Economics 85(1): 173-186.

Conning, Jonathan, and James Robinson. 2007. "Property Rights and the Political Organization of Agriculture." Journal of Development Economics 82(2): 416-47.

Davis, Lance, and Douglass North. 1971. Institutional Change and American Economic Growth. Cambridge: Cambridge University Press.

Demsetz, Harold. 1967. “Toward a Theory of Property Rights.” American Economic Review 57(2): 347-59.

de Soto, Hernando. 2000. The Mystery of Capital. Why Capitalism Triumphs in the West and Fails Everywhere Else. Basic Books: New York. 
De Ferranti, David, Guillermo Perry, Francisco Ferreira, and Michael Walton. 2004. Inequality in Latin America: Breaking with History? Washington D.C.: The World Bank.

Deininger, Klaus, and Songqing Jin. 2005. "The potential of land markets in the process of economic development: evidence from China.” Journal of Development Economics 78(1): 241-270.

Deininger, Klaus, and Songqing Jin. 2006. "Tenure Security and land-related investment: Evidence from Ethiopia." European Economic Review 50(5): 1245-1277.

Deininger, Klaus, Songqing Jin, and Hari Nagarajan. 2008. "Efficiency and equity impacts of rural land rental restrictions: Evidence from India." European Economic Review 52(5): 892-918.

Di Tella, Rafael, Sebastian Galiani, and Ernesto Schargrodsky, 2007. "The Formation of Beliefs: Evidence from the Allocation of Land Titles to Squatters." Quarterly Journal of Economics 122(1): 209-241.

Do, Quy-Toan, and Lakshmi Iyer. 2008. "Land Titling and Rural Transition in Vietnam." Economic Development and Cultural Change, 56(3): 531-579.

FAO. 1981. 1970 World Census of Agriculture: Analysis and International Comparison of the Results. Rome: Food and Agricultural Organization of the United Nations.

Feder, Gershon, and David Feeny. 1991. "Land Tenure and Property Rights: Theory and Implications for Development Policy." The World Bank Economic Review 5(1): 135-153.

Field, Erica, 2005. "Property Rights and Investment in Urban Slums." Journal of the European Economic Association 3(2-3): 279-290.

Field, Erica. 2007. "Entitled to Work: Urban Property Rights and Labor Supply in Peru." Quarterly Journal of Economics 4(122): 1561-1602.

Galiani, Sebastian and Ernesto Schargrodsky. 2005. "Property Rights for the Poor: Effects of Land Titling." Mimeo, Universidad Torcuato di Tella, Buenos Aires.

Gill, Margarita. 2000. "República Dominicana: Tenencia y Mercado de la Tierra.” Santo Domingo: InterAmerican Development Bank.

Gine, Xavier, 2005. "Land Security in Rural Thailand: Evidence from a Property Rights Reform." World Bank Policy Research Working Paper WPS 3734, Washington DC.

Glaeser, Edward, Jose Scheinkman, and Andrei Shleifer. 2003. "The Injustice of Inequality.” Journal of Monetary Economics 50 (1): 199-222.

Goldstein, Markus, and Christopher Udry. 2008. "The Profits of Power: Land Rights and Agricultural Investment in Ghana." The Journal of Political Economy 116(6): 961-1022. 
Gradstein, Mark. 2007. "Inequality, Democracy, and the Protection of Property Rights." Economic Journal 117(516): 252-269.

Jacoby, Hanan, Guo Li, and Scott Rozelle. 2002. "Hazards of Expropriation: Tenure Insecurity and Investment in Rural China." American Economic Review 92(5): 1420-1447.

Jepsen, Lisa, and Christopher Jepsen. 2002. "An Empirical Analysis of Same-sex and Opposite-sex Couples." Demography 39(3): 435-453.

Johnson, Simon, John McMillan, and Christopher Woodruff. 2002. "Property Rights and Finance." American Economic Review 92(5): 1335-1356.

Lanjouw, Jean, and Philip Levy. 2002. "Untitled: A Study of Formal and Informal Property Rights in Urban Ecuador.” The Economic Journal 112(482): 986-1019.

Lanjouw, Jean. 1999. "Information and the Operation of Markets: Tests Based on a General Equilibrium Model of Land Leasing in India." Journal of Development Economics 60(2): 497-527.

Macours, Karen, Manuel Diaz, Javier Molina, and Hector Robles. 2002. "Legal and Institutional Impediments to the Development of Efficient Land Rental Markets in Latin America." Paper prepared for the FAORLC workshop on land rental markets, Santiago, August 1-2.

McFadden, Daniel. 1999. “Discrete Response Models." Unpublished lecture notes, University of California at Berkeley.

Petrongolo, Barbara, and Christopher Pissarides. 2001. "Looking into the Black Box: A Survey of the Matching Function.” Journal of Economic Literature 39(June): 390-431.

Ravallion, Martin. 2001. "Growth, Inequality, and Poverty: Looking Beyond Averages." World Development 29(11): 1803-15.

Suen, Wing, and Hon-Kwong Lui. 1999. "A Direct Test of the Efficient Marriage Market Hypothesis." Economic Inquiry 37(1): 29-46.

Wong, Linda. 2003. "Why do only 5.5\% of Black Men Marry White Women." International Economic Review 44(3): 803-826. 
Table 1. Distribution of transactions by living standard of tenant and landlord in communities with and without recent land invasions

\begin{tabular}{|c|c|c|c|c|c|}
\hline Living & $\mathrm{Li}$ & $\operatorname{stanc}$ & enant & & mber of \\
\hline & Low & Regular & High & Total & observations \\
\hline
\end{tabular}

Communities with recent land invasions

\begin{tabular}{cccccc} 
Low & $52 \%$ & $41 \%$ & $7 \%$ & $100 \%$ & 46 \\
Regular & $21 \%$ & $52 \%$ & $27 \%$ & $100 \%$ & 70 \\
High & $7 \%$ & $33 \%$ & $60 \%$ & $100 \%$ & 45 \\
\hline Total & $26 \%$ & $43 \%$ & $30 \%$ & $100 \%$ & 161
\end{tabular}

Communities without recent land invasions

\begin{tabular}{cccccc} 
Low & $33 \%$ & $48 \%$ & $19 \%$ & $100 \%$ & 54 \\
Regular & $25 \%$ & $45 \%$ & $30 \%$ & $100 \%$ & 47 \\
High & $41 \%$ & $36 \%$ & $23 \%$ & $100 \%$ & 39 \\
\hline Total & $33 \%$ & $43 \%$ & $24 \%$ & $100 \%$ & 140 \\
\hline
\end{tabular}


Table 2. Landlord choice of tenant

Lower level estimation in the nested logit model of the landlord choice in the tenancy market

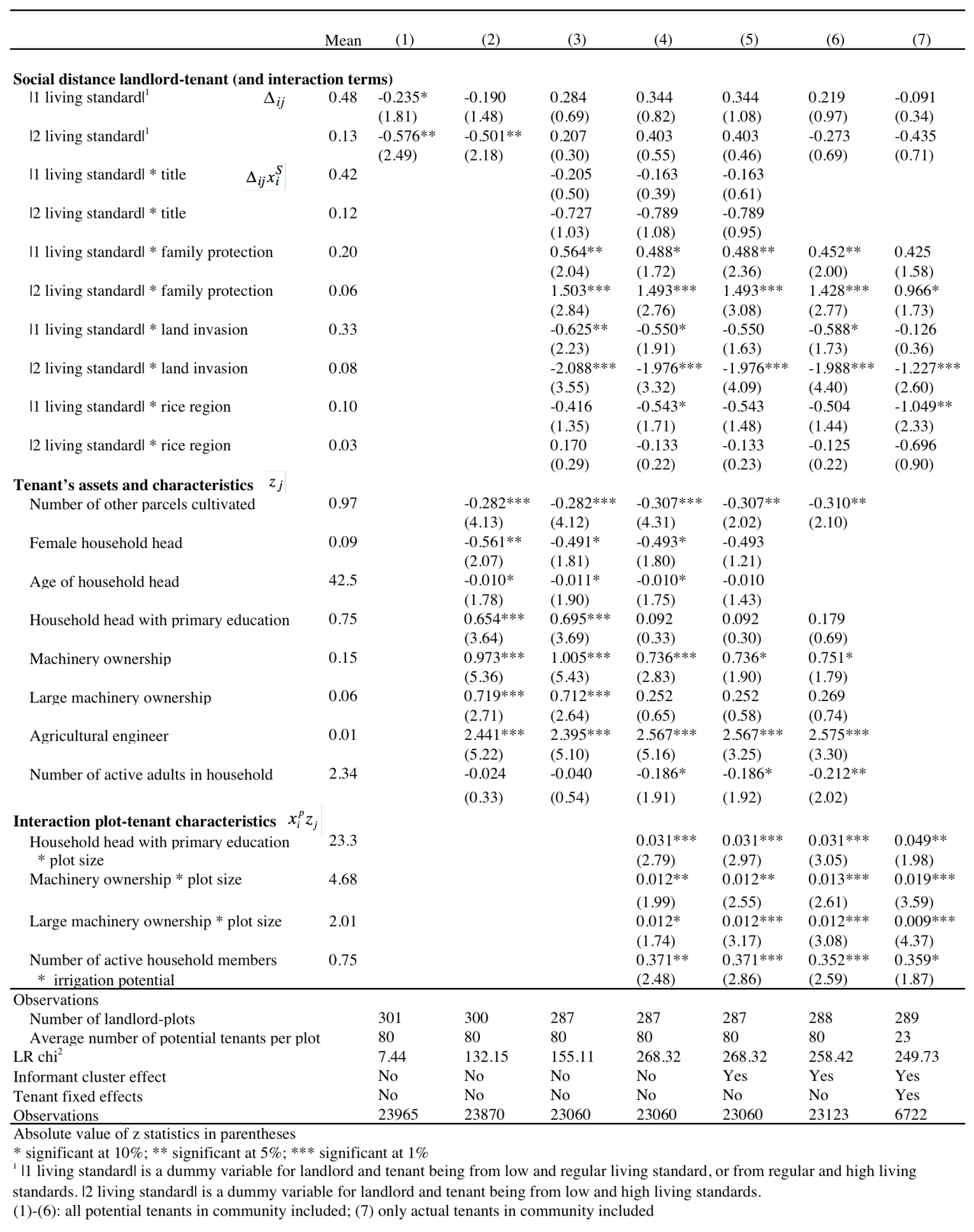


Table 3. I andlord decision of renting out

Upper level estimation in the nested logit model of the landlord choice in the tenancy market

\begin{tabular}{|c|c|c|c|c|c|}
\hline & Mean & $(1)$ & $(2)$ & $(3)$ & $(4)$ \\
\hline Landlord characteristics & & & & & \\
\hline Amount of land owned (ha) & 5.2 & $\begin{array}{l}0.056^{*} \\
(1.89)\end{array}$ & $\begin{array}{l}0.052 \\
(1.47)\end{array}$ & $\begin{array}{l}0.056^{*} \\
(1.88)\end{array}$ & \\
\hline Female household head (dummy) & 0.20 & $\begin{array}{l}1.185^{* * *} * \\
(4.98)\end{array}$ & $\begin{array}{l}1.395 * * * \\
(5.61)\end{array}$ & $\begin{array}{l}1.185 * * * \\
(5.03)\end{array}$ & $\begin{array}{l}1.294 * * * \\
(5.62)\end{array}$ \\
\hline Age of household head & 56 & $\begin{array}{l}0.033^{* * *} \\
(4.18)\end{array}$ & $\begin{array}{l}0.038^{* * *} \\
(4.45)\end{array}$ & $\begin{array}{l}0.033^{* * *} \\
(3.46)\end{array}$ & $\begin{array}{l}0.046^{* * *} \\
(7.04)\end{array}$ \\
\hline Household head with primary education & 0.56 & $\begin{array}{l}-0.057 \\
(0.26)\end{array}$ & $\begin{array}{l}0.010 \\
(0.04)\end{array}$ & $\begin{array}{l}-0.057 \\
(0.20)\end{array}$ & \\
\hline Machinery ownership & 0.25 & $\begin{array}{l}-0.548^{*} \\
(1.77)\end{array}$ & $\begin{array}{l}-0.479 \\
(1.45)\end{array}$ & $\begin{array}{l}-0.548 \\
(1.34)\end{array}$ & \\
\hline Large machinery ownership & 0.07 & $\begin{array}{l}-0.591 \\
(1.15)\end{array}$ & $\begin{array}{l}-0.629 \\
(1.19)\end{array}$ & $\begin{array}{l}-0.591 * * k \\
(2.24)\end{array}$ & \\
\hline Agricultural engineer & 0.01 & $\begin{array}{l}2.729 * * \\
(2.58)\end{array}$ & $\begin{array}{l}2.919 * * * \\
(2.77)\end{array}$ & $\begin{array}{l}2.729 * * \\
(2.48)\end{array}$ & \\
\hline Number of active adults in household & 2.57 & $\begin{array}{l}-0.248 * * * \\
(3.07)\end{array}$ & $\begin{array}{l}-0.184 * * \\
(2.11)\end{array}$ & $\begin{array}{l}-0.248 * * * \\
(2.79)\end{array}$ & \\
\hline Plot characteristics $\quad x_{i}^{p}$ & & & & & \\
\hline Plot size (ha) & 2.5 & $\begin{array}{l}-0.770 \text { *** } \\
(6.12)\end{array}$ & $\begin{array}{l}-0.691 \text { *** } \\
(3.84)\end{array}$ & $\begin{array}{l}-0.770 * * * \\
(4.96)\end{array}$ & $\begin{array}{l}-0.635 \text { *** } \\
(5.95)\end{array}$ \\
\hline Irrigation potential (dummy) & 0.44 & $\begin{array}{l}-0.204 \\
(0.80)\end{array}$ & $\begin{array}{l}-0.347 \\
(1.15)\end{array}$ & $\begin{array}{l}-0.204 \\
(0.50)\end{array}$ & \\
\hline Insecurity of property rights & & & & & \\
\hline Plot with title (dummy) & 0.76 & $\begin{array}{l}0.530 * * \\
(2.25)\end{array}$ & $\begin{array}{l}0.963 * * * \\
(3.11)\end{array}$ & $\begin{array}{l}0.530^{*} \\
(1.76)\end{array}$ & $\begin{array}{l}0.558 * * \\
(2.38)\end{array}$ \\
\hline Land invasions in community (dummy) & 0.75 & $\begin{array}{l}0.288 \\
(1.34)\end{array}$ & & $\begin{array}{l}0.288 \\
(0.91)\end{array}$ & \\
\hline $\begin{array}{l}\text { Many family members in community } \\
\text { (dummy) }\end{array}$ & 0.57 & $\begin{array}{l}-0.289 \\
(1.44)\end{array}$ & $\begin{array}{l}-0.007 \\
(0.03)\end{array}$ & $\begin{array}{l}-0.289 \\
(1.26)\end{array}$ & \\
\hline Rice region (dummy) & 0.45 & $\begin{array}{l}-1.425 * * * \\
(4.83)\end{array}$ & & $\begin{array}{l}-1.425 * * * \\
(2.97)\end{array}$ & $\begin{array}{l}-1.483 * * * \\
(6.87)\end{array}$ \\
\hline Inclusive value $^{a}$ & 5.00 & $\begin{array}{l}0.825 * * * \\
(5.22)\end{array}$ & $\begin{array}{l}0.720 * * * \\
(3.09)\end{array}$ & $\begin{array}{l}0.825 * * * \\
(3.87)\end{array}$ & $\begin{array}{l}0.717 * * * \\
(5.12)\end{array}$ \\
\hline Constant & & $\begin{array}{l}-4.436 * * * \\
(5.20) \\
\end{array}$ & $\begin{array}{l}-5.928 * * * \\
(5.16) \\
\end{array}$ & $\begin{array}{l}-4.436 * * * \\
(4.08) \\
\end{array}$ & $\begin{array}{l}-5.524 * * * \\
(7.88) \\
\end{array}$ \\
\hline $\begin{array}{l}\text { Observations } \\
\text { Informant controls }\end{array}$ & & $\begin{array}{l}697 \\
\text { No }\end{array}$ & $\begin{array}{l}697 \\
\text { Fixed } \\
\text { effects }\end{array}$ & $\begin{array}{l}697 \\
\text { Correlated } \\
\text { errors }\end{array}$ & $\begin{array}{l}700 \\
\text { No }\end{array}$ \\
\hline
\end{tabular}

Robust $\mathrm{z}$ statistics in parentheses - Observations were weighted to account for sampling frame

* significant at $10 \% ; * *$ significant at $5 \%$; ** significant at $1 \%$

${ }^{a}$ Estimation in Table 2 (column 6) reports the first step, used for the calculation of the inclusive values. 
Table 4. Landlord choice of tenant with different specifications: robustness checks

\begin{tabular}{|c|c|c|c|c|c|}
\hline & $\begin{array}{l}(1) \\
\text { Base } \\
\end{array}$ & $\begin{array}{l}(2) \\
\text { Tenant's } \\
\text { class } \\
\end{array}$ & $\begin{array}{l}\text { (3) } \\
\text { Assymetric } \\
\text { Effects }\end{array}$ & $\begin{array}{l}4) \\
\text { Unequal } \\
\text { Distance 1 } \\
\end{array}$ & $\begin{array}{l}5) \\
\text { Assortative } \\
\text { Matching } \\
\end{array}$ \\
\hline \multicolumn{6}{|l|}{ Social Distance landlord-tenant with interaction terms } \\
\hline I1 livingstandardl*family protection & $\begin{array}{l}0.452 * * \\
(2.00)\end{array}$ & & $\begin{array}{l}0.533 \\
(1.40)\end{array}$ & $\begin{array}{l}0.661^{*} \\
(1.86)\end{array}$ & $\begin{array}{l}0.392 \\
(1.57)\end{array}$ \\
\hline 12 livingstandard $*$ family protection & $\begin{array}{l}1.428 * * * \\
(2.77)\end{array}$ & & $\begin{array}{l}0.996^{*} \\
(1.67)\end{array}$ & $\begin{array}{l}1.498 \text { *** } \\
(2.86)\end{array}$ & $\begin{array}{l}1.312 * * * \\
(2.78)\end{array}$ \\
\hline I1 livingstandard|*land invasion & $\begin{array}{l}-0.588^{*} \\
(1.73)\end{array}$ & & $\begin{array}{l}-0.820^{*} \\
(1.80)\end{array}$ & $\begin{array}{l}-0.851 \\
(1.47)\end{array}$ & $\begin{array}{l}-0.642^{*} \\
(1.90)\end{array}$ \\
\hline 12 livingstandard|*land invasion & $\begin{array}{l}-1.988 * * * \\
(4.40)\end{array}$ & & $\begin{array}{l}-2.111^{* *} \\
(2.47)\end{array}$ & $\begin{array}{l}-2.197 * * * \\
(4.72)\end{array}$ & $\begin{array}{l}-2.207 * * * \\
(4.27)\end{array}$ \\
\hline I1 livingstandardl*rice region & $\begin{array}{l}-0.504 \\
(1.44)\end{array}$ & & $\begin{array}{l}-0.585 \\
(1.60)\end{array}$ & $\begin{array}{l}-1.262 * * \\
(2.08)\end{array}$ & $\begin{array}{l}-0.334 \\
(0.89)\end{array}$ \\
\hline 12 livingstandardl*rice region & $\begin{array}{l}-0.125 \\
(0.22)\end{array}$ & & $\begin{array}{l}-0.991 \\
(0.98)\end{array}$ & $\begin{array}{l}-0.329 \\
(0.51)\end{array}$ & $\begin{array}{l}0.198 \\
(0.29)\end{array}$ \\
\hline \multicolumn{6}{|l|}{ Tenant's living standard (and interaction terms) } \\
\hline Regular & & $\begin{array}{l}-0.539 \\
(1.33)\end{array}$ & & & \\
\hline Low & & $\begin{array}{l}-1.330 * * \\
(2.26)\end{array}$ & & & \\
\hline Regular*family protection & & $\begin{array}{l}-0.254 \\
(0.76)\end{array}$ & & & \\
\hline Low*family protection & & $\begin{array}{l}0.196 \\
(0.59)\end{array}$ & & & \\
\hline Regular*land invasion & & $\begin{array}{l}0.206 \\
(0.41)\end{array}$ & & & \\
\hline Low*land invasion & & $\begin{array}{l}0.351 \\
(0.45)\end{array}$ & & & \\
\hline Regular*rice region & & $\begin{array}{l}1.019 \\
(1.61)\end{array}$ & & & \\
\hline Low*rice region & & $\begin{array}{l}0.786 \\
(1.11)\end{array}$ & & & \\
\hline \multicolumn{6}{|c|}{ Difference in productive assets between landlords and tenants } \\
\hline I $\Delta$ age household headl & & & & & $\begin{array}{l}-0.05 / \\
(0.40) \\
0.009\end{array}$ \\
\hline$\Delta$ education level household headl & & & & & $\begin{array}{l}(1.33) \\
0.031\end{array}$ \\
\hline $\mid \Delta$ machinery ownershipl & & & & & $\begin{array}{l}(0.28) \\
0.302^{*} \\
(1.79)\end{array}$ \\
\hline Interaction plot-tenant characteristics & yes & yes & yes & yes & no \\
\hline Assymetric effects social distance & no & no & yes & no & no \\
\hline Difference between high-regular and regular-low & no & no & no & yes & no \\
\hline \multicolumn{6}{|l|}{$\overline{\text { Observations }}$} \\
\hline Number of landlord-plots & 288 & 288 & 288 & 288 & 296 \\
\hline Average number of potential tenants per plot & 80 & 80 & 80 & 80 & 80 \\
\hline
\end{tabular}

All regressions include controls for social distance between landlord and tenant; and tenant characteristics.

Absolute value of $\mathrm{z}$ statistics in parentheses (standard errors clustered by informant)

* significant at $10 \%$; ** significant at $5 \%$; *** significant at $1 \%$.

${ }^{1}$ I1 living standardl is a dummy variable for landlord and tenant being from low and regular living standard, or from regular and high living standards. 12 living standardl is a dummy variable for landlord and tenant being from low and high living standard. 
Table 5. Landlord choice of tenant : futher robustness checks

\begin{tabular}{|c|c|c|c|c|c|c|c|c|c|c|c|}
\hline & Mean & Base & $\begin{array}{c}\text { (2) } \\
\text { Social } \\
\text { distance * } \\
\text { informant } \\
\text { class } \\
\end{array}$ & $\begin{array}{c}\text { (3) } \\
\text { Social distance } \\
\text { informant - } \\
\text { tenant }\end{array}$ & $\begin{array}{c}\text { (4) } \\
\begin{array}{c}\text { Community } \\
\text { cluster }\end{array}\end{array}$ & $\begin{array}{c}\text { (5) } \\
\text { Without } \\
\text { other plots }\end{array}$ & $\begin{array}{c}\text { (6) } \\
\text { Other land } \\
\text { cultivated per } \\
\text { capita }\end{array}$ & $\begin{array}{c}\text { (7) } \\
\text { Other land } \\
\text { cultivated }\end{array}$ & Sharercropping & (9) & $\begin{array}{c}\text { (10) } \\
\text { Social distance } \\
\text { with tenant } \\
\text { characterisics }^{3} \\
\end{array}$ \\
\hline \multicolumn{12}{|c|}{ Social Distance landlord-tenant with interaction terms } \\
\hline I1 livingstandard $*$ family protection & 0.20 & $\begin{array}{c}0.452 * * \\
(2.00)\end{array}$ & $\begin{array}{c}0.480 * * \\
(2.15)\end{array}$ & $\begin{array}{c}0.449 * * \\
(2.01)\end{array}$ & $\begin{array}{c}0.452 * * \\
(2.00)\end{array}$ & $\begin{array}{c}0.437 * \\
(1.92)\end{array}$ & $\begin{array}{c}0.455^{* *} \\
(2.02)\end{array}$ & $\begin{array}{c}0.457 * * \\
(2.03)\end{array}$ & $\begin{array}{c}0.515^{*} \\
(1.88)\end{array}$ & $\begin{array}{c}0.464 * * \\
(1.97)\end{array}$ & $\begin{array}{c}0.450^{* * *} \\
(0.226)\end{array}$ \\
\hline I2 livingstandard $*$ family protection & 0.06 & $\begin{array}{c}1.428 * * * \\
(2.77)\end{array}$ & $\begin{array}{c}1.385 * * * \\
(2.58)\end{array}$ & $\begin{array}{c}1.423 * * * \\
(2.68)\end{array}$ & $\begin{array}{c}1.428 * * * \\
(2.97)\end{array}$ & $\begin{array}{c}1.256 * * * \\
(2.83)\end{array}$ & $\begin{array}{c}1.365 * * * \\
(2.90)\end{array}$ & $\begin{array}{c}1.346 * * * \\
(2.88)\end{array}$ & $\begin{array}{l}1.875^{*} \\
(1.86)\end{array}$ & $\begin{array}{c}1.413 * * * \\
(3.02)\end{array}$ & $\begin{array}{c}1.408 * * * \\
(0.519)\end{array}$ \\
\hline I1 livingstandard $*$ land invasion & 0.33 & $\begin{array}{c}-0.588^{*} \\
(1.73)\end{array}$ & $\begin{array}{c}-0.594 * \\
(1.73)\end{array}$ & $\begin{array}{c}-0.590^{*} \\
(1.72)\end{array}$ & $\begin{array}{c}-0.588^{*} \\
(1.91)\end{array}$ & $\begin{array}{c}-0.561^{*} \\
(1.68)\end{array}$ & $\begin{array}{l}-0.558 \\
(1.64)\end{array}$ & $\begin{array}{r}-0.555 \\
(1.64)\end{array}$ & $\begin{array}{c}-0.599 \\
(1.51)\end{array}$ & $\begin{array}{c}-0.433 * \\
(1.83)\end{array}$ & $\begin{array}{l}-0.566^{*} \\
(0.325)\end{array}$ \\
\hline 12 livingstandard $*$ land invasion & 0.08 & $\begin{array}{c}-1.988^{* * * *} \\
(4.40)\end{array}$ & $\begin{array}{c}-1.997 * * * \\
(4.39)\end{array}$ & $\begin{array}{c}-1.989 * * * \\
(4.36)\end{array}$ & $\begin{array}{c}-1.988^{* * * *} \\
(4.69)\end{array}$ & $\begin{array}{c}-1.902 * * * \\
(4.58)\end{array}$ & $\begin{array}{c}-1.875 * * * \\
(4.35)\end{array}$ & $\begin{array}{c}-1.843 * * * \\
(4.43)\end{array}$ & $\begin{array}{c}-1.649 * \\
(1.95)\end{array}$ & $\begin{array}{c}-1.894 * * * \\
(4.77)\end{array}$ & $\begin{array}{c}-2.192 * * * \\
(0.463)\end{array}$ \\
\hline I1 livingstandard|*rice region & 0.10 & $\begin{array}{r}-0.504 \\
(1.44)\end{array}$ & $\begin{array}{l}-0.486 \\
(1.53)\end{array}$ & $\begin{array}{l}-0.508 \\
(1.47)\end{array}$ & $\begin{array}{c}-0.504 \\
(1.40)\end{array}$ & $\begin{array}{l}-0.497 \\
(1.49)\end{array}$ & $\begin{array}{l}-0.518 \\
(1.54)\end{array}$ & $\begin{array}{l}-0.521 \\
(1.55)\end{array}$ & $\begin{array}{l}-0.447 \\
(1.08)\end{array}$ & $\begin{array}{c}-1.048 * * * \\
(2.69)\end{array}$ & $\begin{array}{l}-0.498 \\
(0.366)\end{array}$ \\
\hline 12 livingstandard $*$ rice region & 0.03 & $\begin{array}{l}-0.125 \\
(0.22)\end{array}$ & $\begin{array}{c}-0.164 \\
(0.31)\end{array}$ & $\begin{array}{l}-0.132 \\
(0.23)\end{array}$ & $\begin{array}{c}-0.125 \\
(0.23)\end{array}$ & $\begin{array}{c}-0.238 \\
(0.53)\end{array}$ & $\begin{array}{c}-0.210 \\
(0.40)\end{array}$ & $\begin{array}{l}-0.265 \\
(0.53)\end{array}$ & $\begin{array}{l}-1.378 \\
(1.60)\end{array}$ & $\begin{array}{c}-0.930^{*} \\
(1.70)\end{array}$ & $\begin{array}{l}-0.343 \\
(0.657)\end{array}$ \\
\hline \multicolumn{12}{|c|}{ Social Distance landlord-tenant with additional controls } \\
\hline I1 livingstandard|*informant class & 0.43 & & $\begin{array}{l}0.289 \\
(0.53)\end{array}$ & & & & & & & & \\
\hline I2 livingstandard|*informant class & 0.12 & & $\begin{array}{c}-0.468 \\
(0.69)\end{array}$ & & & & & & & & \\
\hline |1 livingstandard(informant-tenant)| & 0.51 & & & $\begin{array}{c}-0.016 \\
(0.12)\end{array}$ & & & & & & & \\
\hline |2 livingstandard(informant-tenant)| & 0.01 & & & $\begin{array}{l}0.046 \\
(0.06)\end{array}$ & & & & & & & \\
\hline I1 livingstandard।*land Gini ${ }^{2}$ & 0.42 & & & & & & & & & $\begin{array}{c}-8.534 * * * \\
(3.90)\end{array}$ & \\
\hline 2 livingstandard|*land Gini ${ }^{2}$ & 0.12 & & & & & & & & & $\begin{array}{c}-10.299 * * * \\
(3.66)\end{array}$ & \\
\hline \multicolumn{12}{|l|}{ Tenant's assets and characteristics } \\
\hline Number of other plots cultivated & 0.97 & $\begin{array}{c}-0.310 * * \\
(2.10)\end{array}$ & $\begin{array}{c}-0.314 * * \\
(2.16)\end{array}$ & $\begin{array}{c}-0.311 * * \\
(2.10)\end{array}$ & $\begin{array}{c}-0.310^{*} \\
(1.85)\end{array}$ & & & & $\begin{array}{l}-0.312 \\
(1.57)\end{array}$ & $\begin{array}{c}-0.332 * * \\
(2.32)\end{array}$ & $\begin{array}{c}-0.318 * * \\
(0.152)\end{array}$ \\
\hline Amount of other land cultivated & 34 & & & & & & $\begin{array}{c}-0.003 * \\
(1.86)\end{array}$ & & & & \\
\hline Amount of other land cultivated per capita & 16 & & & & & & & $-0.006^{*}$ & & & \\
\hline \multicolumn{12}{|l|}{ Observations } \\
\hline Number of landlord-plots & & 288 & 288 & 288 & 288 & 288 & 288 & 288 & 175 & 288 & 288 \\
\hline Average number of potential tenants per plot & & 80 & 80 & 80 & 80 & 80 & 80 & 79 & 80 & 80 & 80 \\
\hline Informant correlation & & Yes & Yes & Yes & - & Yes & Yes & Yes & Yes & Yes & Yes \\
\hline
\end{tabular}

Yes

* significant at $10 \%$; ** significant at $5 \% ; * * *$ significant at $1 \%$. Absolute value of $\mathrm{z}$ statistics in parentheses.

${ }^{1}$ I1 living standardl is a dummy variable for landlord and tenant being from low and regular living standard, or from regular and high living standards.

12 living standardl is a dummy variable for landlord and tenant being from low and high living standards.

${ }^{2}$ High coefficients of interaction terms reflect low variation between land Ginis across communities

${ }^{3}$ The tenant characteristics interacted with social distance are those listed in Table 2. 


\begin{tabular}{|c|c|c|c|c|c|c|c|}
\hline & \multicolumn{2}{|c|}{ Insecure property rights } & \multicolumn{3}{|c|}{ Secure property rights } & \multirow[b]{2}{*}{$\begin{array}{c}\text { Title, } \\
\text { protection, and } \\
\text { no conflict } \\
\text { with capital } \\
(6) \\
\end{array}$} & \multirow[b]{2}{*}{$\begin{array}{c}\text { Only } \\
\text { capital } \\
(7) \\
\end{array}$} \\
\hline & $\begin{array}{c}\text { Insecure } \\
\text { Observed } \\
\text { values } \\
(1) \\
\end{array}$ & $\begin{array}{l}\text { erty rights } \\
\text { Simulated } \\
\text { values } \\
(2) \\
\end{array}$ & $\begin{array}{c}\text { Title, } \\
\text { protection, and } \\
\text { no conflict } \\
(3) \\
\end{array}$ & $\begin{array}{c}\text { Only } \\
\text { title } \\
(4) \\
\end{array}$ & $\begin{array}{c}\text { Only } \\
\text { protection, and } \\
\text { no conflict } \\
(5) \\
\end{array}$ & & \\
\hline \multicolumn{8}{|l|}{ Efficiency effects: Market size } \\
\hline Number of plots rented out* & 302 & 307 & $21 \%$ & $6 \%$ & $14 \%$ & $54 \%$ & $30 \%$ \\
\hline Number of tenants* & 246 & 245 & $13 \%$ & $6 \%$ & $9 \%$ & $55 \%$ & $45 \%$ \\
\hline Total area rented (ha)* & 526 & 543 & $20 \%$ & $4 \%$ & $15 \%$ & $66 \%$ & $40 \%$ \\
\hline \multicolumn{8}{|l|}{ Efficiency effects: Factor allocation } \\
\hline Land/labor ratio on plots rented out by poor ${ }^{\mathrm{a}}$ & 1.01 & 1.13 & 2.94 & 1.24 & 3.1 & 3.46 & 1.32 \\
\hline Land/labor ratio on plots rented out by non-poor ${ }^{\mathrm{a}}$ & 2.28 & 3.44 & 3.11 & 3.42 & 2.91 & 2.11 & 2.55 \\
\hline Machinery on plots rented out by poor ${ }^{\mathrm{b}}$ & 0.23 & 0.39 & 0.59 & 0.38 & 0.61 & - & - \\
\hline Machinery on plots rented out by non-poor ${ }^{\mathrm{b}}$ & 0.54 & 0.65 & 0.61 & 0.65 & 0.61 & - & - \\
\hline Land/labor ratio on plots owned by the poor ${ }^{c}$ & 0.88 & 0.75 & 1.42 & 0.80 & 1.42 & 1.75 & 0.79 \\
\hline Land/labor ratio on plots owned by the non-poor ${ }^{c}$ & 2.50 & 2.64 & 2.52 & 2.66 & 2.42 & 1.97 & 2.22 \\
\hline \multicolumn{8}{|l|}{ Equity effects: Access to land } \\
\hline Number of plots rented out to poor tenants* & 89 & 89 & $65 \%$ & $10 \%$ & $57 \%$ & $180 \%$ & $75 \%$ \\
\hline Number of poor tenants* & 85 & 86 & $59 \%$ & $10 \%$ & $52 \%$ & $151 \%$ & $72 \%$ \\
\hline Total area rented to poor (ha)* & 102 & 114 & $63 \%$ & $11 \%$ & $55 \%$ & $310 \%$ & $115 \%$ \\
\hline Percent of plots rented out to poor tenants & 29 & 29 & 40 & 30 & 40 & 53 & 39 \\
\hline Percent of poor among tenants & 35 & 35 & 50 & 36 & 49 & 57 & 42 \\
\hline Percent of total area rented to poor & 19 & 21 & 29 & 22 & 28 & 52 & 32 \\
\hline
\end{tabular}

Simulations are based on estimations in Tables 2 (col. 6) and 3 (col. 4).

* Columns 3-7 report the \% change relative to the simulated value in column 2 .

${ }^{\text {a }}$ Total amount of land cultivated by the tenant household divided by the number of adult households members

${ }^{\mathrm{b}}$ Dummy variable equals to 1 if either landowner or tenant owns machinery

${ }^{\mathrm{c}}$ Weighed average of plots rented to others and owner-cultivated plots 